\title{
Nitrogen-climate interactions in US agriculture
}

\author{
G. Philip Robertson - Tom W. Bruulsema • Ron J. Gehl • \\ David Kanter - Denise L. Mauzerall • C. Alan Rotz • \\ Candiss O. Williams
}

Received: 4 June 2012/ Accepted: 24 September 2012/Published online: 23 October 2012

(C) The Author(s) 2012. This article is published with open access at Springerlink.com

\begin{abstract}
Agriculture in the United States (US) cycles large quantities of nitrogen $(\mathrm{N})$ to produce food, fuel, and fiber and is a major source of excess reactive nitrogen $(\mathrm{Nr})$ in the environment. Nitrogen lost from cropping systems and animal operations moves to waterways, groundwater, and the atmosphere. Changes in climate and climate variability may further affect the ability of agricultural systems to conserve $\mathrm{N}$. The $\mathrm{N}$ that escapes affects climate directly through the emissions of nitrous oxide $\left(\mathrm{N}_{2} \mathrm{O}\right)$, and indirectly through the loss of nitrate $\left(\mathrm{NO}_{3}{ }^{-}\right)$, nitrogen oxides $\left(\mathrm{NO}_{x}\right)$ and ammonia to downstream and downwind ecosystems that then emit some of the $\mathrm{N}$ received as $\mathrm{N}_{2} \mathrm{O}$ and $\mathrm{NO}_{x}$. Emissions of $\mathrm{NO}_{x}$ lead to the formation of tropospheric ozone, a greenhouse gas that can also harm crops directly. There
\end{abstract}

G. P. Robertson ( $\square)$

Department of Plant, Soil and Microbial Sciences, WK Kellogg Biological Station, and Great Lakes Bioenergy Research Center, Michigan State University, Hickory

Corners, MI, USA

e-mail: robert30@msu.edu

T. W. Bruulsema

International Plant Nutrition Institute, Guelph,

ON, Canada

R. J. Gehl

Department of Soil Science, NC State University, Raleigh, NC, USA

D. Kanter · D. L. Mauzerall

Woodrow Wilson School of Public and International

Affairs, Princeton University, Princeton, NJ, USA are many opportunities to mitigate the impact of agricultural $\mathrm{N}$ on climate and the impact of climate on agricultural N. Some are available today; many need further research; and all await effective incentives to become adopted. Research needs can be grouped into four major categories: (1) an improved understanding of agricultural $\mathrm{N}$ cycle responses to changing climate; (2) a systems-level understanding of important crop and animal systems sufficient to identify key interactions and feedbacks; (3) the further development and testing of quantitative models capable of predicting $\mathrm{N}$-climate interactions with confidence across a wide variety of crop-soil-climate combinations; and (4) socioecological research to better understand the incentives necessary to achieve meaningful deployment of realistic solutions.

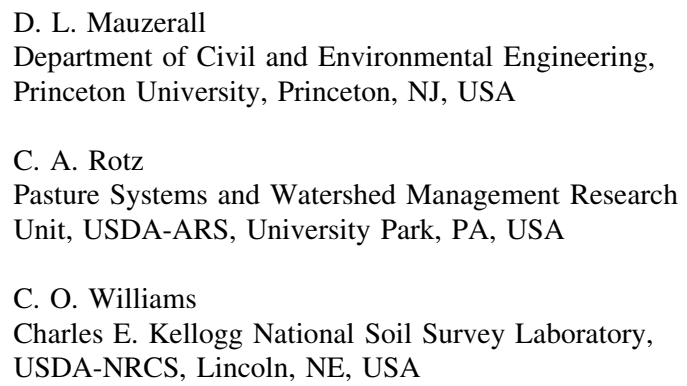


Keywords Nitrate - Nitrous oxide - Ozone · Greenhouse gases $\cdot$ Mitigation $\cdot$ Methane $\cdot$ Fertilizer

\section{Introduction}

Nitrogen $(\mathrm{N})$ is an essential element for plant and animal growth, and our ability to harness $\mathrm{N}$ in its reactive forms has fundamentally transformed how we produce food. The Haber-Bosch process, the industrial manufacture of ammonia $\left(\mathrm{NH}_{3}\right)$, greatly accelerated the global production and dissemination of synthetic $\mathrm{N}$ fertilizers. This development marked the most significant human interference in the natural $\mathrm{N}$ cycle by removing a fundamental limit on crop yields, allowing for the adoption of high yielding cultivars and a corresponding increase in global harvests. Today, the approximately $100 \mathrm{Tg}$ of reactive nitrogen $(\mathrm{Nr})$ supplied from synthetic fertilizers is roughly equal to the total $\mathrm{N}$ fixed in natural terrestrial ecosystems (Houlton et al., this issue). Global per capita rates of $\mathrm{N}$ fertilizer consumption per year have risen from $0.2 \mathrm{~kg}$ in 1900 to $2 \mathrm{~kg}$ in 1950 to nearly $14 \mathrm{~kg}$ in 2000 (Smil 2001). Inevitably, this huge advance in global $\mathrm{N}$ use has been accompanied by considerable growth in $\mathrm{Nr}$ loss to the environment exacerbating atmospheric greenhouse gas (GHG) forcing. For example, atmospheric concentrations of nitrous oxide $\left(\mathrm{N}_{2} \mathrm{O}\right)$, the most long-lived form of gaseous $\mathrm{Nr}$, have risen $18 \%$ since 1750 (Houghton et al. 2001).

Fertilizers, manure, and legume dinitrogen $\left(\mathrm{N}_{2}\right)$ fixation are the three main inputs of $\mathrm{N}$ to US agricultural soils. All three sources have been increasing over the past two decades, while the rate at which $\mathrm{N}$ is removed from cropping systems at harvest has been increasing at a slightly higher rate (Fig. 1), resulting in a slightly greater proportion of input recovery in 2007 than in 1987 (ERS 2012). The major forms of fertilizer used in the US are granular urea, fluid urea-ammonium nitrate (UAN), and anhydrous ammonia, with the use of ureabased fertilizers increasing and the use of anhydrous ammonia decreasing over time. Fertilizer $\mathrm{N}$ use in North America is forecast to grow 2-3\% per year from 2010 to 2016 (Heffer and Prud'homme 2011), and has been projected by one group to double to $28 \mathrm{Tg}$ by 2030 (Tenkorang and Lowenberg-DeBoer 2009).

Nitrogen can take nine forms in terrestrial ecosystems based on different oxidative states (Robertson and Vitousek 2009). It is lost from agricultural systems in

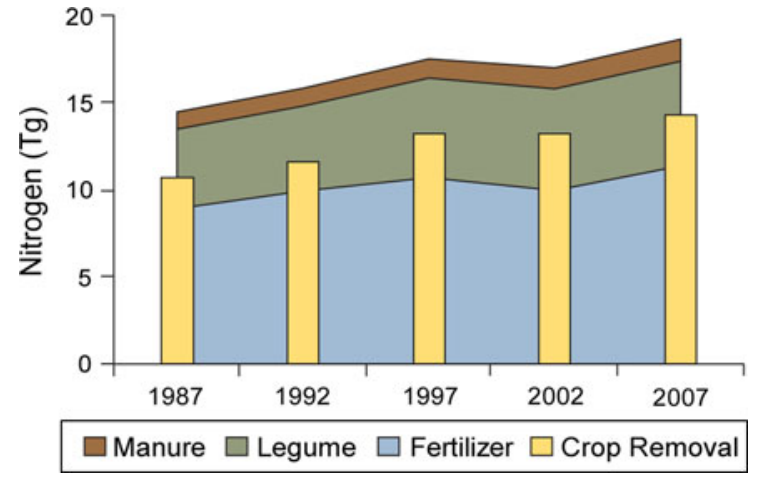

Fig. 1 Inputs of $\mathrm{N}$ to US agricultural land, including recoverable manure, legume $\mathrm{N}_{2}$ fixation, and commercial fertilizers, as compared to removal by crops (adapted from IPNI 2012)

several of these forms; most of it less than a year after it enters the system (Galloway et al. 2003). Atmospheric emissions can occur as nitrogen dioxide $\left(\mathrm{NO}_{2}\right)$, nitric oxide (NO), $\mathrm{N}_{2} \mathrm{O}, \mathrm{N}_{2}$ or $\mathrm{NH}_{3}$ (Pinder et al., this issue; for the radiative forcing impacts of these compounds), while waterways receive inputs of nitrate $\left(\mathrm{NO}_{3}{ }^{-}\right)$and dissolved organic nitrogen (DON) via leaching and runoff. Reactive $\mathrm{N}$ lost in one form can be converted to other forms of $\mathrm{Nr}$ and can "cascade" through several media and systems, contributing to a number of types of environmental pollution before returning to its original atmospheric form, $\mathrm{N}_{2}$ (Galloway et al. 2003; Houlton et al., this issue). Therefore any policy tackling $\mathrm{N}$ pollution must note the myriad of potential environmental sources and fates of $\mathrm{N}$ in the agricultural $\mathrm{N}$ cycle (Fig. 2) and attempt as holistic an approach as possible to avoid unintended outcomes.

Major factors sustaining demand for $\mathrm{N}$ fertilizer use in the US include the outlook for continued large areas of corn cultivation, supported now by biofuel production goals and in the future by burgeoning food demand. At the same time, higher prices for fertilizer and pressures on producers for higher environmental performance are encouraging increased adoption of emerging fertilizer technologies such as precision agriculture and enhanced-efficiency fertilizers in controlled-release form or formulated with inhibitors of urease or nitrification.

Here we address the sources and fates of $\mathrm{N}$ in both cropping systems and animal agriculture and then assess some of the effects of climate change on the US agricultural $\mathrm{N}$ cycle as well as the effects of $\mathrm{N}$ use on climate forcing. We then summarize a number of 




Fig. 2 Pathways of $\mathrm{N}$ cycling in agricultural ecosystems. Transformations of $\mathrm{N}$ shown in solid lines occur in all ecosystems; those shown with dashed lines are particular to (or particularly important within) agricultural systems. Major fluxes of $\mathrm{N}$ include, $A$, additions of industrial fertilizer; $B$, additions of organic $\mathrm{N}$ in manure and mulches; $C$, biological $\mathrm{N}_{2}$ fixation by microbes symbiotically associated with plants and by free-living microorganisms; $D$, atmospheric deposition of reactive $\mathrm{N}$ in oxidized forms $\left(\mathrm{NO}_{x}\right) ; E$, atmospheric deposition of $\mathrm{NH}_{3}$ and $\mathrm{NH}_{4}{ }^{+} ; F$, mineralization of organic $\mathrm{N}$ via mobilzation of amino acids through the action of extracellular enzymes; $G$, mineralization of organic $\mathrm{N}$ via release of $\mathrm{NH}_{4}^{+}$by microbes; $H$, nitrification of $\mathrm{NH}_{4}^{+}$to $\mathrm{NO}_{3}^{-}$; $I$, plant uptake of available

mitigation opportunities and current policy efforts before concluding with future research needs.

\section{Sources and fates of $\mathbf{N}$ in agriculture}

\section{Cropping systems}

Agriculture in the US encompasses many different cropping systems designed to produce a diverse array of food, forage, fuel, and fiber products. All of these systems require adequate $\mathrm{N}$, the nutrient that most commonly limits crop productivity, and all but a few leguminous crops depend on added $\mathrm{N}$ to achieve profitable yields.
$\mathrm{N} ; J$, microbial immobilization-the uptake of biologically available $\mathrm{N}$ by microbes; $K$, losses of $\mathrm{N}$ in harvested products; $L$, losses of $\mathrm{N}$ in solution to streamwater and groundwater; $\mathrm{M}$, denitrification to $\mathrm{N}_{2} ; N, \mathrm{NH}_{3}$ volatilization from both fields and intensive animal production systems; $O$, losses of $\mathrm{N}_{2} \mathrm{O}$ produced during nitrification and denitrification; $P$, losses of $\mathrm{NO}_{x}$ produced during nitrification and denitrification; $Q$, uptake of organic $\mathrm{N}$ by microbes during decomposition; $R$, dissimilatory reduction of $\mathrm{NO}_{3}{ }^{-}$to $\mathrm{NH}_{4}{ }^{+} ; S$, consumption of plant $\mathrm{N}$ by animals; $T$, flux of $\mathrm{N}$ to soil from plant litter; and $U$, flux of $\mathrm{N}$ to soil from excretion or animal death (from Robertson and Vitousek 2009)

\section{Cropping system $N$ sources}

Legumes acquire their $\mathrm{N}$ from the atmosphere via rhizobial symbionts that reduce $\mathrm{N}_{2}$ to forms that can be used by plants for protein synthesis. Many legumessoybeans and alfalfa among them-can meet $100 \%$ of their $\mathrm{N}$ needs via $\mathrm{N}_{2}$ fixation, but more commonly a fraction of the $\mathrm{N}$ is provided by soil from the microbial conversion of soil organic matter (SOM) to $\mathrm{NH}_{4}{ }^{+}$and $\mathrm{NO}_{3}{ }^{-}$. Most of the $\mathrm{N}_{2}$ that is fixed ends up being assimilated into plant tissue, but some escapes from the roots to soil as root exudates. A portion of the plantassimilated $\mathrm{N}$ is removed in crop harvest; the remainder becomes plant residue and decomposes to become SOM, ready for mineralization and subsequent crop 
uptake or loss from the ecosystem during the following seasons. When legumes are planted as fallow or winter cover crops following the main crop harvest, all of the $\mathrm{N}_{2}$ fixed becomes SOM as the cover crop is killed prior to planting the subsequent primary crop.

Synthetic fertilizer makes up the biggest source of $\mathrm{N}$ added to US cropping systems. Rates of fertilizer $\mathrm{N}$ additions typically range from $<100 \mathrm{~kg} \mathrm{~N} \mathrm{ha}^{-1}$ year $^{-1}$ for small grains like wheat and perennial biofuel crops like switchgrass, to $>200 \mathrm{~kg} \mathrm{~N}^{-1}$ year $^{-1}$ for high-yielding corn and grass forage crops and some horticultural crops (Ribaudo et al. 2011). Theoretically, only as much $\mathrm{N}$ needs to be added as is removed in crop harvest, but crop $\mathrm{N}$ use is commonly inefficient. On average, only about $50 \%$ of added $\mathrm{N}$ fertilizer is removed in annual grain crop harvest, for example (Robertson 1997).

Best practice calls for applying $\mathrm{N}$ at a time that is as close to the $\mathrm{N}$ need of the crop as possible to avoid excessive loss. In corn, for example, this usually means starter $\mathrm{N}$ at planting and the remainder following initial crop growth. In irrigated corn, fertilizer can be applied throughout the season in irrigation water. Often, however, equipment and labor availability together with uncertain weather drive decisions to add $\mathrm{N}$ fertilizer well before crop $\mathrm{N}$ needs. In 2005, for example, almost one-third of US corn cropland was fertilized the fall before spring planting (Ribaudo et al. 2011), leading to substantial potentials for $\mathrm{N}$ loss.

Nitrogen fertilizer additives and slow-release formulations are designed to delay added $\mathrm{N}$ from entering the soil's soluble $\mathrm{N}$ pool until crop needs are greatest. Additives include nitrification inhibitors, which slow the transformation of $\mathrm{NH}_{4}{ }^{+}$to $\mathrm{NO}_{3}{ }^{-}$(Robertson and Groffman 2007). As a cation, $\mathrm{NH}_{4}{ }^{+}$is less susceptible to leaching loss than is $\mathrm{NO}_{3}{ }^{-}$. Although $\mathrm{NO}_{3}{ }^{-}$is the form of $\mathrm{N}$ utilized by most crops, it also is the form that is most readily lost to the environment through leaching or denitrification to $\mathrm{N}_{2} \mathrm{O}, \mathrm{NO}_{x}\left[\mathrm{NO}+\mathrm{NO}_{2}\right]$, and $\mathrm{N}_{2}$. Slow-release formulations usually coat the $\mathrm{N}$ fertilizer particle with a slowly dissolving shell of another compound or polymer that reacts to soil temperature and moisture. Additives and slow-release formulations are not widely used due to greater cost and inconsistent performance.

Manure represents the third major source of exogenous $\mathrm{N}$ to most US cropping systems. Approximately $6 \mathrm{Tg}$ of manure $\mathrm{N}$ are produced annually in the US
(USEPA 2011a). Because manure is often produced by livestock consuming grain imported from long distances and is expensive to transport, only a small percentage is returned to the field of origin; most manure is applied to nearby fields close to animal feeding operations. This regional $\mathrm{N}$ imbalance leads to less efficient nutrient cycling with greater losses to the environment (Fig. 3; Lanyon and Beegle 1989). Domestic animals are the largest source of US $\mathrm{NH}_{3}$ emissions, accounting for $\sim 1.6 \mathrm{Tg} \mathrm{N}_{\text {year }}{ }^{-1}$ (USEPA 2011a). Certain forms of manure are more susceptible to volatilization than others because of their $\mathrm{pH}$ and $\mathrm{NH}_{3}$ content. Typical annual emissions of $\mathrm{NH}_{3}$ range from $40-1000 \mathrm{~kg} \mathrm{~N} / \mathrm{Mg}$ from cattle and swine and 64-160 kg N/Mg from poultry, depending upon the type of housing and manure handling system used (Rotz 2004).

Soil organic matter is a fourth source of $\mathrm{N}$ in US cropping systems. While important on an annual basis-about $50 \%$ of the $\mathrm{N}$ needs of fertilized crops are met by SOM mineralization-in most longcropped soils SOM levels are stable because mineralized $\mathrm{N}$ is replaced by $\mathrm{N}$ in new crop residues as they decompose to SOM. Thus, SOM is not generally an important source of $\mathrm{Nr}$ in the environment except on recently converted lands (e.g., Gelfand et al. 2011) or on high SOM soils such as drained Histosols, which may quickly lose $\mathrm{C}$ and $\mathrm{N}$ on conversion to agriculture. There is some evidence, however, that longcropped soils once thought to be equilibrated are newly losing SOM, perhaps because of climate change (e.g. Senthilkumar et al. 2009).

\section{Cropping system $N$ fates}

The fate of $\mathrm{N}$ applied to cropland depends on many factors, some under management control and others related to soil, climate, and other environmental attributes. Once applied to soil, added N goes through a number of complex transformations, mostly biological, that lead to four major alternative fates (see Fig. 2): (1) plant uptake and subsequent removal in harvest; (2) loss to surface and groundwater via hydrologic flow as $\mathrm{NO}_{3}{ }^{-}$, DON, and particulate $\mathrm{N}$; (3) loss to the atmosphere as $\mathrm{N}_{2} \mathrm{O}, \mathrm{NO}_{x}, \mathrm{NH}_{3}$, or $\mathrm{N}_{2}$; and (4) storage in the cropping system as inorganic $\mathrm{N}$, in SOM derived from crop residues and microbial biomass, or, for perennial grass or tree crops, in long-lived plant parts such as roots and wood. 


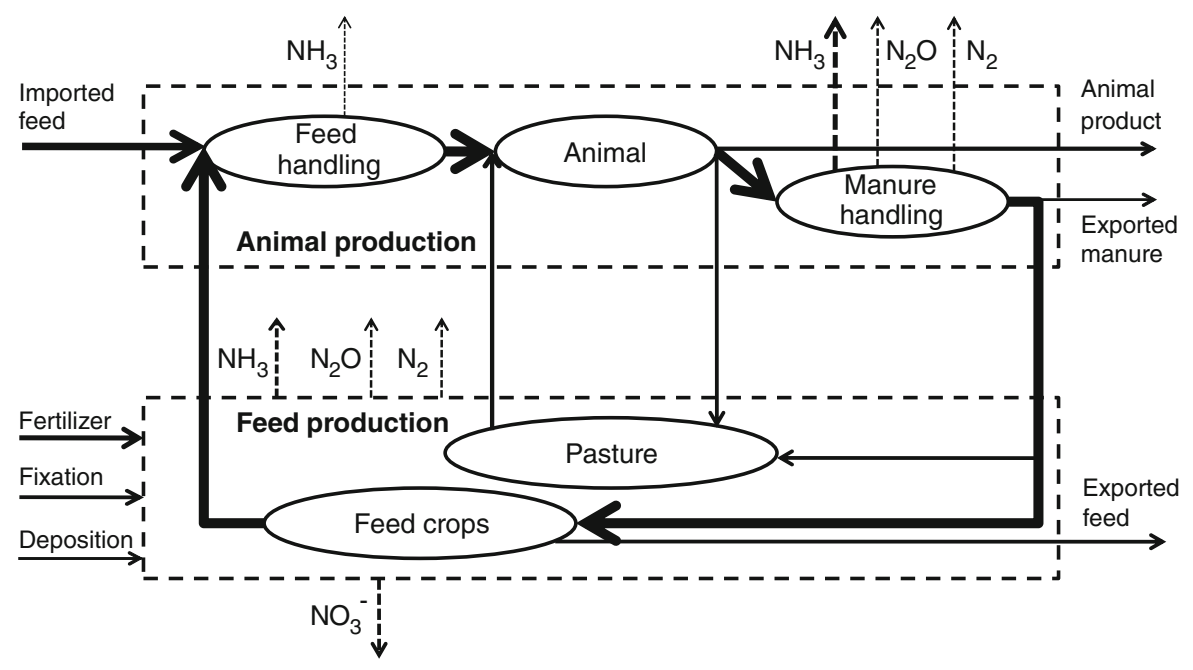

Fig. $3 \mathrm{~N}$ flows through an integrated feed and animal production system. In the animal production portion of the system (upper part of figure), $\mathrm{N}$ is lost to the environment primarily in manure handling as $\mathrm{NH}_{3}, \mathrm{~N}_{2} \mathrm{O}$, and $\mathrm{N}_{2}$. Some $\mathrm{N}$ is exported in animal products and manure, but most is transferred in manure to the feed production system (lower part of diagram) where it is taken up by forage and feed crops, with some lost as

The hydrologic loss of $\mathrm{NO}_{3}{ }^{-}$is typically the major vector of $\mathrm{N}$ lost to the environment from cropping systems that receive rainfall in excess of evapotranspiration. This loss of $\mathrm{NO}_{3}{ }^{-}$can also be high from irrigated systems in drier climates when water applied exceeds crop transpiration need by only a few percent (Gehl et al. 2005). Hydrologic DON loss is minor in most cropping systems (van Kessel et al. 2009), as is particulate $\mathrm{N}$ loss in erosion, which usually represents the translocation of organic $\mathrm{N}$ from one part of the landscape to another rather than loss to the environment-although in areas of high erosion particulate $\mathrm{N}$ can be lost to surface waters via direct runoff.

Ammonium $\left(\mathrm{NH}_{4}{ }^{+}\right)$loss from cropland tends to be important only when manure is applied to surface soils or when anhydrous ammonia or urea fertilizers are misapplied to dry soil, such that the $\mathrm{NH}_{3}$ that is added as anhydrous ammonia or formed from urea escapes to the atmosphere before it can be dissolved in the soil solution as $\mathrm{NH}_{4}{ }^{+}$. Fertilizer misapplication in this way is inefficient and is more likely to occur during extended dry periods.

Nitrous oxide and NO are produced in soil by both nitrifying and denitrifying bacteria (Robertson and Groffman 2007). Nitrification is the oxidation of $\mathrm{NH}_{4}^{+}$ to $\mathrm{NO}_{3}{ }^{-}$with $\mathrm{NO}$ and $\mathrm{N}_{2} \mathrm{O}$ being metabolic by-products
$\mathrm{NH}_{3}, \mathrm{~N}_{2} \mathrm{O}, \mathrm{N}_{2}$, and $\mathrm{NO}_{3}{ }^{-}$. Some of the $\mathrm{N}$ taken up is exported as surplus feed to other systems; most is used on-farm for animal production. Imported $\mathrm{N}$ includes that from fertilizer, biological $\mathrm{N}_{2}$ fixation, and deposition during feed production and during animal production as imported feed to make up feed production shortfalls. Line weights represent the relative amounts of flow among pathways

that escape to the atmosphere. Denitrification is the reduction of $\mathrm{NO}_{3}{ }^{-}$to $\mathrm{NO}, \mathrm{N}_{2} \mathrm{O}$, and $\mathrm{N}_{2}$. The rates of $\mathrm{N}_{2} \mathrm{O}$ and $\mathrm{NO}$ production are highly variable in most soils, and are related both to the factors that affect rates of nitrification (mainly $\mathrm{NH}_{4}{ }^{+}$availability) and denitrification (mainly $\mathrm{NO}_{3}{ }^{-}, \mathrm{C}$, and low $\mathrm{O}_{2}$ availability) as well as soil factors such as $\mathrm{pH}$ that affect the proportion of the end products that are emitted as $\mathrm{NO}$ and $\mathrm{N}_{2} \mathrm{O}$ (Robertson and Groffman 2007).

An important control on the rate of $\mathrm{N}$ gas production is the amount of $\mathrm{N}$ available to the bacteria that carry out the reactions. In almost all but very sandy soils, rates of nitrification and denitrification increase with increasing pools of inorganic $\mathrm{N}$ (e.g., $\mathrm{NO}_{3}{ }^{-}$, $\mathrm{NH}_{4}{ }^{+}$), and likewise, the rates of $\mathrm{N}_{2} \mathrm{O}$ and $\mathrm{NO}$ formation are best predicted by inorganic $\mathrm{N}$ availability. In unfertilized soil, $\mathrm{N}$ available to the bacteria that produce these gases is largely controlled by rates of $\mathrm{N}_{2}$ fixation, SOM turnover, and $\mathrm{N}$ deposition. In most cropped soils this $\mathrm{N}$ is largely controlled by rates of fertilization and SOM turnover. Because plants are good competitors for inorganic $\mathrm{N}$, plant uptake can reduce the amount of $\mathrm{N}$ that would otherwise be available for $\mathrm{N}$ gas production or hydrologic loss.

Nitrogen use efficiency (NUE) - and in particular $\mathrm{N}$-fertilizer use efficiency-is therefore a good general 
metric of $\mathrm{N}$ conservation in cropping systems. Maximizing the fertilizer $\mathrm{N}$ that makes it into the crop will, in general, minimize the $\mathrm{N}$ that is free for loss to the environment. The objective of crop $\mathrm{N}$ management is to improve the efficiency of plant use of $\mathrm{N}$ fertilizers. Strategies to improve system-wide fertilizer use efficiency are therefore of utmost importance for both reducing the impact of climate on crop $\mathrm{N}$ use and for reducing the impact of agriculture on climate, as discussed later.

\section{Animal systems}

Animal agriculture in the US today encompasses a number of different domesticated animals raised for meat, fiber, milk, and eggs in a variety of housing arrangements ranging from high-density confinedanimal feeding operations (CAFOs) to extensive rangeland. All systems have in common the provision of high quality feed and forage that contains protein- $\mathrm{N}$ in excess of the animals' $\mathrm{N}$ need. Excess $\mathrm{N}$ is excreted and subsequently available for loss to the environment, where it has a number of potential fates.

\section{Animal system $N$ sources}

Animal agriculture in the US produces about $131 \mathrm{Tg}$ of meat, eggs, dairy and other animal products using production systems that vary widely by animal species, type of product, and the economic, geographic and cultural characteristics of the production region (ERS 2011). The manure produced by farm animals is considered the major source of gaseous $\mathrm{NH}_{3}$ emission in the US (USEPA 2011a). Manure is a significant contributor to $\mathrm{N}_{2} \mathrm{O}$ and $\mathrm{NO}_{x}$ fluxes both during handling and following soil application (CAST 2004), where it is subject to the same potential fates as synthetic $\mathrm{N}$ additions. Manure applied to fields without growing crops is susceptible to substantial $\mathrm{N}$ loss when the manure $\mathrm{N}$ is transformed from organic to inorganic (e.g., $\mathrm{NH}_{4}{ }^{+}$and $\mathrm{NO}_{3}{ }^{-}$) forms. At a very general level, animal production systems involve the production of feed, preparation and delivery of feed rations to the animals, and the removal and recycling of manure nutrients. The overall production strategy greatly affects the efficiency of $\mathrm{N}$ use and its influence on the environment.

The major animal species used for animal agriculture in the US include dairy and beef cattle, swine, and poultry. Cattle are ruminant animals that require a different feeding strategy than non-ruminants such as swine and poultry (Hristov et al. 2011). Most swine, poultry and beef feedlot systems are managed as independent feeding operations (top half of Fig. 3), where most or all feed is imported, often from long distances.

The production of all confined animal species requires large amounts of $\mathrm{N}$ for feed. For all species, protein requirements must be met for maximum production. Protein is comprised of amino acids required by all organisms for maintenance, growth, and reproduction (NRC 1994, 1998, 2000, 2001). Animals require 20 essential amino acids in amounts that vary with animal age and productivity. Proteins on average contain $16 \% \mathrm{~N}$; therefore matching amino acid levels in rations to those required by the animal is complex and bears strongly on efficient $\mathrm{N}$ use. Unused protein and non-protein $\mathrm{N}$ in animal diets is excreted in manure where it can be lost to the environment as $\mathrm{Nr}$.

During harvest and storage, a small portion of the protein in feed is lost and the remainder can be transformed to different forms (Rotz and Muck 1994). For example, a large portion of the forage fed to cattle is preserved through ensiling, which breaks down plant proteins to forms that are used less efficiently by the animals (Rooke and Hatfield 2003).

Much progress has been made in recent years in determining the nutrient requirements of animals and matching those requirements to that available in feed rations in order to maximize production (NRC 1994, 1998, 2000, 2001). For ruminant animals, suitable fiber levels must be maintained for proper rumen function, which enforces the use of forage in diets and limits the amount of grain and other concentrate feeds that can be used. Some amino acids are required to meet the requirements of microorganisms in the rumen while others are needed in the intestinal tract and must make it through the rumen intact (NRC 2000, 2001). Preparing rations that supplement available forage with the proper amino acids to meet animal requirements is difficult due to varying amounts and types of forage available though the year along with their varying nutrient concentrations. Grazing animals provide an additional challenge since the producer has less control over their diets. Pasture forage tends to have more protein and more rapidly degrading protein than is required, which leads to less efficient $\mathrm{N}$ use and greater N excretion (Van Soest 1994). A study on 
grazing dairy farms in the northeastern US has shown total protein was being overfed by $20-80 \%$ (Soder and Muller 2007).

Non-ruminant animal feeding does not have the complication of fiber requirements. Grains and other concentrate feeds have a more consistent concentration of protein and other nutrients, so protein requirements can be met more precisely. Synthetic amino acids are also commonly used to meet nutritional requirements with greater accuracy throughout animal growth cycles (Keshavarz and Austic 2004).

\section{Animal system $N$ fates}

In general, 65-90\% of the $\mathrm{N}$ consumed in feed is excreted in manure with the remainder retained in body tissue and the milk, eggs, or other products produced (Hristov et al. 2011; Rotz 2004). With good feeding practices for cattle and swine, about $50 \%$ of the $\mathrm{N}$ excreted in feces is in a relatively stable organic form. The remainder, including most of the excess $\mathrm{N}$ consumed, is excreted in urine as urea. For poultry, a large portion of the excreted $\mathrm{N}$ is uric acid, which decomposes to form urea. When deposited on the floor of the housing facility, the urea comes in contact with urease enzymes, which rapidly transform the urea $\mathrm{N}$ to $\mathrm{NH}_{4}{ }^{+}$. At a rate dependent upon temperature, $\mathrm{pH}$ and other manure characteristics, the $\mathrm{NH}_{4}^{+}$forms $\mathrm{NH}_{3}$, which is readily volatilized (Hristov et al. 2011; Montes et al. 2009).

On a barn floor, for example, where manure is removed at least once per day, $\mathrm{NH}_{3}$ emissions vary with temperature and are relatively low in cold winter weather (Montes et al. 2009). In warm weather or on a surface such as an open lot where manure is not removed, nearly all of the urea- $\mathrm{N}$ can be lost to the atmosphere as $\mathrm{NH}_{3}$ (Hristov et al. 2011; Rotz 2004). Some housing systems use a bedded pack, whereby manure and bedding materials accumulate on the barn floor. With this strategy, a portion of the $\mathrm{NH}_{4}{ }^{+}$is absorbed into the bedding material, emitting more $\mathrm{NH}_{3}$ than if it were it deposited on a scraped floor, but less than if it were deposited in an open lot. Bedded pack and open lot surfaces both provide aerobic and anaerobic conditions to support both nitrification and denitrification, creating emissions of $\mathrm{N}_{2} \mathrm{O}$ and $\mathrm{N}_{2}$ (Rotz 2004).

Manure removed from barns can be handled in solid, semi-solid, slurry or liquid forms. Solid manure is relatively dry, often scraped from open lot surfaces where most of the labile $\mathrm{N}$ has been emitted as $\mathrm{NH}_{3}$ (Hristov et al. 2011). Semi-solid manure is formed using bedding material to absorb manure moisture. This type of manure is typically not stored for long periods and may be spread on crop and pastures each day of the year as it is produced. Slurry is formed by scraping manure from the floor of free stall and similar barns designed to use less bedding material. Liquid manure is typically formed by using a solids separator to remove a major portion of the manure particles, leaving the manure solution with less than $5 \%$ dry matter content. Manure solids can be composted and used as bedding material, with most of the $\mathrm{NH}_{4}{ }^{+}$ remaining in the liquid portion (Meyer et al. 2007). Both slurry and liquid manure are typically stored for 4-6 months and in some cases up to a full year to allow the nutrients to be applied to fields at a time when they are best used by growing crops or grassland. However, this requires a storage capacity that many operations lack and consequently it is not unusual for manure to be spread on frozen fields or pastures during the winter.

During long term manure storage, the organic $\mathrm{N}$ portion in the manure slowly decomposes, producing $\mathrm{NH}_{4}{ }^{+}$. If semi-solid manure is stored, it is placed in a stack where $\mathrm{NH}_{3}$ emissions occur and nitrification and denitrification processes generate $\mathrm{N}_{2} \mathrm{O}, \mathrm{NO}_{x}$ and $\mathrm{N}_{2}$ emissions. About 10-20\% of the $\mathrm{N}$ entering storage is lost mainly as $\mathrm{NH}_{3}$ (Rotz 2004). Slurry manure is typically stored in a tank. When manure is continually added to the surface of the tank, up to $30 \%$ of the $\mathrm{N}$ can be lost as $\mathrm{NH}_{3}$, but little or no $\mathrm{N}_{2} \mathrm{O}$ escapes, because anaerobic conditions inhibit nitrification, thus preventing conversion to $\mathrm{NO}_{3}{ }^{-}$and subsequent denitrification. When manure is pumped into the bottom of the tank, a crust of manure solids can form on the surface, reducing emissions of $\mathrm{NH}_{3}$ by up to $80 \%$. However, nitrification and denitrification can occur within this crust, thus emitting $\mathrm{N}_{2} \mathrm{O}$ (Petersen and Miller 2006). Liquid manure is commonly stored in a lined earthen basin or lagoon where $\mathrm{NH}_{3}, \mathrm{~N}_{2} \mathrm{O}$ and $\mathrm{N}_{2}$ losses are relatively high (Harper et al. 2004). When a multiple stage lagoon (e.g., flow from a facultative to anaerobic lagoon) is used, up to $90 \%$ of the $\mathrm{N}$ can be lost or removed between the inlet and outlet.

Most manure is applied to crop or grassland as fertilizer. Methods of manure application include broadcast application to the field surface, subsurface 
injection, and irrigation. When manure is broadcast spread, any remaining $\mathrm{NH}_{4}{ }^{+}$in the manure is rapidly volatilized to $\mathrm{NH}_{3}$ (Gènermont and Cellier 1997), although at least half can be retained if the manure is tilled into the soil within several hours of application (Rotz et al. 2011). Subsurface injection can also greatly reduce or even eliminate $\mathrm{NH}_{3}$ emission depending upon injection depth (Rotz et al. 2011; Ndegwa et al. 2008). Irrigation is often used to apply liquid manure, and a portion of manure- $\mathrm{N}$ content is lost as $\mathrm{NH}_{3}$ during irrigation. However, if the manure infiltrates rapidly into the soil, $\mathrm{N}$ will be retained as $\mathrm{NH}_{4}{ }^{+}$(Sommer et al. 2003). Application losses vary from $2 \%$ of the manure $\mathrm{N}$ applied through deep soil injection to $30 \%$ of the $\mathrm{N}$ applied through surface spreading without soil incorporation (Rotz 2004).

\section{Climate-nitrogen interactions}

Climate and agricultural $\mathrm{N}$ interact in complex ways. Some of the interactions are direct, such as changes in climate patterns that prompt farmers to adapt their cropping systems to higher temperatures and changes in rainfall patterns. Some of the interactions are indirect, such as changing consumption patterns of oil and natural gas (used as feedstocks for $\mathrm{NH}_{3}$ production) as a result of climate policies, which may subsequently affect fertilizer prices and, thus, fertilizer consumption and consequently $\mathrm{Nr}$ escape. However, agriculture is not only affected by climate change, but also contributes to climate change by contributing GHGs to the atmosphere. We consider both climate effects on $\mathrm{N}$ cycling and farm $\mathrm{N}$ cycle effects on climate change in the sections below.

\section{Climate effects on agricultural $\mathrm{N}$ cycling}

Climate change affects agricultural $\mathrm{N}$ cycling mainly through its impact on changing patterns of temperature and rainfall. Effects also occur due to changes in the chemical climate-in particular via changes in atmospheric concentrations of ozone $\left(\mathrm{O}_{3}\right)$ and carbon dioxide $\left(\mathrm{CO}_{2}\right)$.

\section{Ozone, climate, and agricultural yield impacts}

Nitrogen oxides $\left(\mathrm{NO}_{x}=\mathrm{NO}+\mathrm{NO}_{2}\right)$ are key precursors of tropospheric $\mathrm{O}_{3}$. Ozone harms crops and thereby affects crop $\mathrm{N}$ use and $\mathrm{Nr}$ escape. Ozone is produced in the troposphere by the catalytic reactions of $\mathrm{NO}_{x}$ with carbon monoxide $(\mathrm{CO})$, methane $\left(\mathrm{CH}_{4}\right)$, and non-methane volatile organic compounds (NMVOCs) in the presence of sunlight (photolysis). Production of $\mathrm{O}_{3}$ is a highly non-linear function of the emission of these precursors (NRC 1991), some of which $\left(\mathrm{NO}_{x}\right.$ and $\mathrm{CH}_{4}$ in particular) are produced by agriculture (Yienger and Levy 1995; Karl et al. 2009; Hudman et al. 2010). Due to these non-linearities, the $\mathrm{O}_{3}$ production efficiency per unit $\mathrm{NO}_{x}$ emitted is high in rural areas. Furthermore, increases in temperature can also lead to higher rates of precursor emission and $\mathrm{O}_{3}$ formation.

Field experiments in the US, Europe, and Asia have shown that surface $\mathrm{O}_{3}$ causes substantial damage to many plants and agricultural crops, including increased susceptibility to disease, reduced growth and reproductive capacity, increased senescence, and reductions in crop yields (Mauzerall and Wang 2001). Based on the large-scale experimental studies of the National Crop Loss Assessment Network (NCLAN) conducted in the US in the 1980s (Heagle 1989; Heck 1989), the US Environmental Protection Agency (USEPA) estimated that the yields of about one third of US crops were reduced by $10 \%$ due to ambient $\mathrm{O}_{3}$ concentrations during this time (USEPA 1996). Model simulations of $\mathrm{O}_{3}$ used with the established NCLAN concentration and yield response relationships predict larger effects for grain crops for 2000 and 2030 (Avnery et al. 2011a, b).

Agricultural soils are a minor but significant source of atmospheric $\mathrm{NO}_{x}$ (Robertson and Vitousek 2009), with $\mathrm{NO}_{x}$ emissions ( " $P$ " in Fig. 2) typically enhanced following fertilizer application, precipitation, and elevated temperature (Butterbach-Bahl et al. 2009). In a recent top-down analysis, emissions from agricultural soils summed to about $14 \%$ of global surface emissions (Jaeglé et al. 2005). Hence, increasing fertilizer use in response to a growing global population requiring food and biofuel in a warming climate may lead to higher soil $\mathrm{NO}_{x}$ emissions and consequently increased $\mathrm{O}_{3}$ production with resulting adverse impacts on crop yields. Emissions of $\mathrm{NO}_{x}$ from industrial and vehicle sources are expected to decrease in the US over the next several decades, increasing the relative contribution from agriculture to total US $\mathrm{NO}_{x}$ emissions (Peel et al., this issue). Thus $\mathrm{NO}_{x}$ emissions from agricultural regions will likely have a proportionally larger impact on rural $\mathrm{O}_{3}$ concentrations, and hence on crop yields, in the future. 
Large-scale, comprehensive field studies in the US and Europe in the 1980s/1990s showed a wide range of crop sensitivities to $\mathrm{O}_{3}$, both among different crops and within cultivars of the same crop (Heagle 1989; Heck 1989; Krupa et al. 1998). Crop varieties used today appear to exhibit sensitivity to $\mathrm{O}_{3}$ that is on average at least as great as that seen in earlier field studies (Long et al. 2005; Emberson et al. 2009). Ozone sensitivity may thus be an overlooked factor in cultivar choice, especially if variety development and breeding trials are conducted in areas of low or moderate $\mathrm{O}_{3}$ impact.

The observed correlation between surface $\mathrm{O}_{3}$ and temperature in polluted regions points to a detrimental effect of warming. Although there is regional variability, observations in the US have shown higher surface $\mathrm{O}_{3}$ concentrations as temperatures increase (see Fig. 4). In addition, coupled chemistry-climate model simulations indicate that with no change in the emission of $\mathrm{O}_{3}$ precursors, climate warming itself will likely result in increased surface $\mathrm{O}_{3}$ concentrations in many parts of the US (Jacob and Winner 2009). This is frequently termed the "climate penalty" and it applies to penalties both for agricultural productivity and human health (Peel et al., this issue). Projected increases in $\mathrm{O}_{3}$ vary among models, but are typically in the $1-10 \mathrm{ppb}$ range over the next several decades, implying that stronger emission controls will be needed in order to meet a given $\mathrm{O}_{3}$ air quality standard. Although higher water vapor in the future climate is expected to decrease $\mathrm{O}_{3}$ over remote oceanic regions, the opposite may occur for polluted continental regions (Jacob and Winner 2009).

\section{Temperature effects}

Temperature will affect both crop and animal production systems. Warming temperatures will affect crop productivity, mainly because most physiological processes related to crop growth and yield are highly sensitive to temperature, and crops have a specific temperature range for maximum yields (Hatfield et al. 2008, 2011). The response of crops to temperature may be complex, non-linear, and exhibit threshold effects. Maximum crop yields for corn, soybeans, and cotton are found at temperatures of 29,30 , and $32{ }^{\circ} \mathrm{C}$, respectively. The slopes of the decline in yield above optimum temperatures are significantly steeper than the incline in yield below optimal temperature (Schlenker and Roberts 2009).

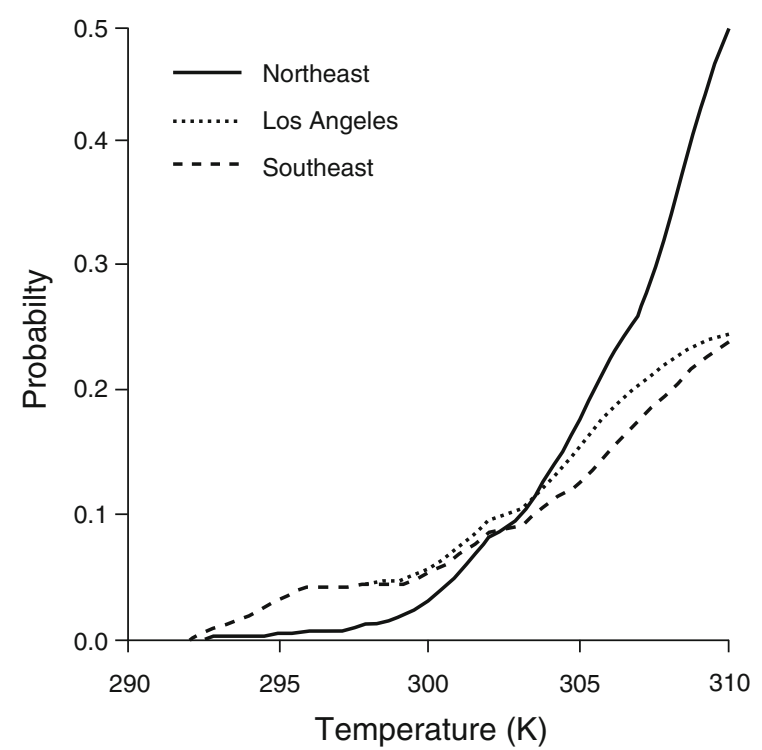

Fig. 4 Observed probability that maximum daily average ozone will exceed $80 \mathrm{ppb}$ for a given daily maximum temperature (1980-1998 data) for different parts of the US (adapted from Jacob and Winner 2009)

There is debate over the effect of temperature on agricultural yields. Recent research indicates that from 1980 to 2008 global yields of maize and wheat declined by 3.8 and $5.5 \%$, respectively, relative to a counterfactual without climate trends (Lobell et al. 2011). However, these global declines were driven by responses in low latitude countries, where temperatures in tropical locations may exceed optimal ranges, resulting in a significant reduction in yields. In contrast, higher temperatures may benefit crop productivity in some mid- to high latitude regions by increasing the length of the growing season as well as the amount of land suitable for cultivation. Fischer et al. (2005) project an increase in potential agricultural land of 40, 16, 64, and $10 \%$ in North America, Europe, Russia, and East Asia, respectively, driving potential global cereal production improvements of 1.9-3.0 Gt by 2080 depending on the climate change scenario considered. However, temperature also affects the rate of plant development, and even brief exposure to higher temperatures may shorten growing periods and threaten yields if exposure occurs during important development stages such as flowering and grain filling (Wheeler et al. 2000; Wollenweber et al. 2003).

Higher temperatures may also accelerate SOM turnover, leading to lower soil C stores (Davidson and 
Janssens 2006; Knorr et al. 2005, Conant et al. 2008) even in arable soils. In some cases (e.g., Senthilkumar et al. 2009), accelerated $\mathrm{C}$ loss has been attributed to higher wintertime temperatures, which in cropped systems would release additional $\mathrm{N}$ to the soil at a time when plants are not available to immobilize it.

The balance between warmer temperatures and increasing/decreasing rainfall will be important for determining whether there is an increase or decrease in emissions of $\mathrm{Nr}$ gases $\left(\mathrm{N}_{2} \mathrm{O}, \mathrm{NO}_{x}\right.$; " $O$ " and " $P$ " in Fig. 2) per unit of fertilizer applied to cropping systems. More research is needed to illuminate these changes on both a regional and global basis.

Projected temperature changes will also directly and indirectly affect animal production. The primary direct impact will be related to heat stress due to increasing ambient temperatures. Heat stress causes reduced feed intake, increased water intake, higher body temperatures, increased respiration, decreased activity, and hormonal and metabolic changes, which in turn lead to reduced production, reduced reproduction, and increased mortality (Nardone et al. 2010). Under our current climate, heat stress is estimated to cause an annual economic loss of 1.7-2.4 billion dollars in the US (St-Pierre et al. 2003). Future shortages of water may also directly impact animal production and exacerbate the heat stress issue.

Indirect effects include changes in feeding practices due to the adaptation of crop type, yield, and nutritive content to changes in climate. Furthermore, adaptation to new feeds may also affect feed value and $\mathrm{N}$ use efficiency. Rates of $\mathrm{NH}_{3}$ emissions are also very sensitive to temperature (Montes et al. 2009), such that increasing ambient temperatures will also increase this source of $\mathrm{N}$ loss throughout all phases of manure handling. Overall, the net effect of these changes in the $\mathrm{N}$ cycle in response to heat stress is likely a reduction in $\mathrm{N}$ use efficiency of animal systems.

\section{Precipitation impacts on crop response to and recovery of $N$}

The quantity, frequency, and intensity of precipitation and evapotranspiration throughout much of the world will likely be altered due to rising global surface temperatures (Meehl et al. 2007). Precipitation increased by $7-12 \%$ in the middle to high latitudes of the northern hemisphere during the twentieth century, particularly during autumn and winter when rains and snowfall were more intense. However, these increases varied both spatially and temporally (IPCC 2001). Areas that experience increases in mean precipitation, particularly tropical and high latitude regions, are also projected to have an increased intensity of precipitation events. Geographic regions where precipitation decreases (e.g., most subtropical and mid-latitude regions) are expected to have increased sporadic precipitation events of increased strength, with longer dry periods between events. Projected increases in summer dryness from increasing surface temperatures also indicate a greater risk of probable drought. Notable changes in precipitation extremes have already been observed, and projected changes would extend trends already underway (USGCRP 2009; Meehl et al. 2007).

Intensification of precipitation in spring and excessively wet winters can delay crop planting, increase plant diseases, retard plant growth, and cause flooding, runoff, and erosion-all of which can harm crop production and reduce crop yields and economic returns. Additionally, extreme wet cycles can result in substantial losses of $\mathrm{Nr}$ to the environment, through transport and leaching of $\mathrm{NO}_{3}^{-}$(" $L$ " in Fig. 2) especially in regions where artificial subsurface drainage (e.g., tiles) removes excess soil water from fields, and through gaseous losses of $\mathrm{N}_{2} \mathrm{O}$ ( " $O$ " in Fig. 2). Nitrate leaching is a problem that is exacerbated when large amounts of soil $\mathrm{NO}_{3}{ }^{-}$are present after fertilizer application and before the period of peak crop $\mathrm{N}$ demand (" $I$ " in Fig. 2) (Davidson et al. 2012).

Increases in drought frequency and intensity also adversely affect crop growth and yield, ultimately impacting nutrient use and uptake efficiency. Drought also increases the demand for irrigation which affects regional water resources as well as $\mathrm{Nr}$ movement in the soil system. Fertilizer $\mathrm{N}$ is typically applied prior to or shortly after crop planting ( " $A$ " in Fig. 2), and is usually applied on the basis of expected yields at rates to produce historically maximum crop yields for a given location. Thus, environmental factors that limit crop growth and yield during the growing season, including both drought and excessive moisture, would result in especially high $\mathrm{Nr}$ loss due to reduced crop uptake, particularly when significant precipitation events or prolonged wet periods occur after the growing season.

Occurrences of drought or excessive moisture affect not only crop growth and subsequent nutrient use, but also soil $\mathrm{N}$ turnover within agricultural systems 
("F", " $G$ ", " $H$ ", " $J$ ", " $R$ ", " $Q$ " in Fig. 2). Short- and long-term fluctuations in precipitation are closely tied to the spatial and temporal $\mathrm{N}$ dynamics of the system. During periods of drought or seasonal water deficit, an overall decrease in $\mathrm{N}$ turnover typically follows as a result of shifts in soil and atmospheric $\mathrm{N}$ dynamics.

Ecosystem $\mathrm{N}$ loss mechanisms are highly sensitive to fluctuations and variability in both precipitation timing and amount (Larsen et al. 2011). Seasonal and periodic droughts affect net primary productivity, plant $\mathrm{N}$ uptake, soil microbial activity, $\mathrm{N}_{2} \mathrm{O}$ flux, $\mathrm{NO}_{3}{ }^{-}$leaching, and denitrification (Emmett et al. 2004; Davidson et al. 2008; Sardans et al. 2008; Larsen et al. 2011). Further, drought reduces net soil respiration and when soil is wetted following a drought, large fluxes of $\mathrm{NO}$ and $\mathrm{N}_{2} \mathrm{O}$ rapidly occur (Davidson 1992; Bergsma et al. 2002; Borken et al. 2006). The pronounced affects of extreme precipitation fluxes and drought on soil $\mathrm{Nr}$ dynamics thus affect soil $\mathrm{N}$ availability to planted crops and the response of crops to fertilizer $\mathrm{N}$ sources.

\section{Effect of increased ambient $\mathrm{CO}_{2}$ on crop $\mathrm{N}$ demand}

Atmospheric $\mathrm{CO}_{2}$ concentrations have increased from 270 to $384 \mathrm{ppm}$ since the Industrial Revolution. Numerous studies have evaluated crop response to rising $\mathrm{CO}_{2}$ concentration, sometimes referred to as the $\mathrm{CO}_{2}$ fertilization effect. Many crop plants, including wheat and soybean, demonstrate increased growth and seed yield in response to increased $\mathrm{CO}_{2}$. Elevated $\mathrm{CO}_{2}$ may also improve crop water use efficiency and drought tolerance by reducing conductance of $\mathrm{CO}_{2}$ and water vapor through leaf stomata.

Larsen et al. (2011) report increased $\mathrm{C}$ to $\mathrm{N}$ ratio (C/ $\mathrm{N})$ in aboveground plant biomass of a semi-natural ecosystem with elevated $\mathrm{CO}_{2}$. However, they conclude that drought dominated the plant response to elevated $\mathrm{CO}_{2}$, and that the reduced $\mathrm{N}$ turnover stemming from drought and warming may act to reduce the potential plant growth response to rising atmospheric $\mathrm{CO}_{2}$.

Crop response depends in part on the major photosynthetic pathway employed by a given crop. Plants with a $\mathrm{C}_{3}$ metabolism have different $\mathrm{CO}_{2}$ and temperature response curves than those with a $\mathrm{C}_{4}$ pathway. Most crops grown in the US are $\mathrm{C}_{3}$ plants, but several $\mathrm{C}_{4}$ crops are economically important including corn, sorghum, sugar cane, and warm season grasses proposed for biofuel feedstocks, such as switchgrass (Panicum virgatum) and giant miscanthus (Miscanthus $\times$ giganteus).

Leakey et al. (2009) recently summarized the results of 15 major Free-Air $\mathrm{CO}_{2}$ Enrichment (FACE) experiments that measured the impact of elevated $\mathrm{CO}_{2}$ on plants over multiple seasons and/or crop life cycles. They reported several important effects, including:

- Photosynthetic $\mathrm{C}$ uptake of $\mathrm{C}_{3}$ plants is enhanced by elevated $\mathrm{CO}_{2}$ despite acclimation of photosynthetic capacity, with an expected $\mathrm{C}$ gain of $19-46 \%$ for plants grown at $\mathrm{CO}_{2}$ levels projected for the mid-century;

- For $\mathrm{C}_{3}$ plants, photosynthetic $\mathrm{N}$ use efficiency (PNUE), determined as the net amount of $\mathrm{CO}_{2}$ assimilated per unit of leaf $\mathrm{N}$, increases with increasing $\mathrm{CO}_{2}$. The observed increase is primarily driven by enhanced $\mathrm{CO}_{2}$ uptake and not by redistribution of foliar $\mathrm{N}$.

- Plant water use consistently declines with increasing $\mathrm{CO}_{2}$, resulting in greater soil moisture availability. The decline in water use is driven by reduced stomatal conductance coupled with decreased canopy evapotranspiration with elevated $\mathrm{CO}_{2}$.

- Carbon uptake in $\mathrm{C}_{4}$ plants is not directly stimulated by elevated $\mathrm{CO}_{2}$ except in drought situations. However, there is a potential for increased $\mathrm{C}_{4}$ plant growth at elevated $\mathrm{CO}_{2}$. Decreased water use and reduced drought stress at elevated $\mathrm{CO}_{2}$ improves $\mathrm{C}_{4}$ plant water relations and indirectly enhances photosynthesis, growth, and yield.

- The increase in $\mathrm{C}_{3}$ photosynthesis stemming from elevated $\mathrm{CO}_{2}$ in FACE experiments was greater than the increases in biomass or crop yield, suggesting that photosynthetic response cannot itself predict crop performance. Prior predictions of crop growth based on theory and observations in laboratories or growth chambers systematically overestimated yields of major food crops compared with FACE experimental results.

Cumulatively, the effects of elevated $\mathrm{CO}_{2}$ impact the growth response and potential yield of crops. The impact of these changes on crop $\mathrm{N}$ uptake and demand and crop response to fertilizer $\mathrm{N}$ warrants further investigation.

Elevated $\mathrm{CO}_{2}$ may also directly affect soil $\mathrm{N}$ transformations and gaseous $\mathrm{Nr}$ loss due to increased soil $\mathrm{C}$ availability and changes in soil-plant water 
relations (Luo and Mooney 1999). Soil processes that involve $\mathrm{Nr}$ may be altered indirectly through changes in plant biomass, root exudates, and microbial community structure (Cantarel et al. 2011).

Greenhouse gas forcing due to use of $\mathrm{N}$ in agriculture

Agricultural N contributes to GHG forcing in several ways. Farming results in the direct release of several GHGs and GHG precursors, including $\mathrm{CO}_{2}, \mathrm{~N}_{2} \mathrm{O}$, $\mathrm{NO}_{x}$, and $\mathrm{CH}_{4}$. Some of these gases are also released indirectly by farming - in downwind and downstream ecosystems that receive $\mathrm{Nr}$ initially in the form of $\mathrm{NH}_{3}$ volatilized and $\mathrm{NO}_{3}{ }^{-}$leached from farm systems. Tillage also has a well-known and direct effect on $\mathrm{CO}_{2}$ release from farmed soils (Davidson and Ackerman 1993; Grandy and Robertson 2006), and there may be an interaction with $\mathrm{N}$ use. Additionally, the manufacture of $\mathrm{N}$ fertilizer emits $\mathrm{CO}_{2}$ directly to the atmosphere.

\section{Nitrous oxide emissions}

Nitrous oxide is not reactive in the troposphere but is a powerful GHG-approximately 300 times more potent than $\mathrm{CO}_{2}$ on a molar basis, and atmospheric concentrations have increased consistently from $270 \mathrm{ppb}$ during pre-industrial times to today's concentrations of approximately $320 \mathrm{ppb}$. This increase in $\mathrm{N}_{2} \mathrm{O}$ has contributed about $6 \%$ of the total GHG forcing that drives climate change (Forster et al. 2007). While this is not a large percentage, the anthropogenic $\mathrm{N}_{2} \mathrm{O}$ flux is equivalent to $1.0 \mathrm{Pg} \mathrm{C}$ year $^{-1}$ when converted to $\mathrm{C}$ equivalents using 100-year global warming potentials (Robertson 2004; Prinn 2004), which is of the same magnitude as the contemporary net atmospheric $\mathrm{CO}_{2}$ increase of $4.1 \mathrm{Pg} \mathrm{C}$ year $^{-1}$ (Canadell et al. 2007).

About $80 \%$ of the $\mathrm{N}_{2} \mathrm{O}$ added to the atmosphere annually by human activities is associated with agriculture. About $60 \%$ of this is emitted from agricultural soils, $30 \%$ from animal waste treatment, and $10 \%$ from burning crop residues and vegetation cleared for new agricultural activities (Robertson 2004; Houghton et al. 2001). Row crop agriculture is thus responsible for about $50 \%$ of the global anthropogenic $\mathrm{N}_{2} \mathrm{O}$ flux (Robertson 2004). Due in part to its high global warming potential, $\mathrm{N}_{2} \mathrm{O}$ is a major target for offset projects that can be included in cap and trade markets due to the high payback associated with the mitigation of $\mathrm{N}_{2} \mathrm{O}$ emissions (Millar et al. 2010).

Fluxes of $\mathrm{N}_{2} \mathrm{O}$ are highest where inorganic $\mathrm{N}$ is readily available (Bouwman et al. 1993). Thus soils fertilized with $\mathrm{N}$ are major sources of $\mathrm{N}_{2} \mathrm{O}$, although fluxes can also be high in soils with high SOM stores that are rapidly mineralizing $\mathrm{N}$, such as drained organic soils (e.g., Histosols in the USDA soil taxonomy nomenclature). Hundreds of field experiments have shown the amount of $\mathrm{N}$ fertilizer applied to be the strongest manageable predictor of $\mathrm{N}_{2} \mathrm{O}$ fluxes in all major cropping systems. In addition to the amount of $\mathrm{N}$ applied, $\mathrm{N}_{2} \mathrm{O}$ fluxes can also be influenced by the formulation, timing, and placement of $\mathrm{N}$ fertilizers, and by agronomic practices that affect $\mathrm{N}$ availability in soils, such as tillage and residue management.

On average, about $0.5-3 \%$ of $\mathrm{N}$ applied to cropped soils is emitted as $\mathrm{N}_{2} \mathrm{O}$ to the atmosphere (Stehfest and Bouwman 2006; Linquist et al. 2012). The range is due mainly to variation among sites and is well-recognized and expected based on soils, climate, and fertilizer practices. Furthermore, emission rates may be even higher where $\mathrm{N}$ input levels exceed the demand of the crop (e.g., McSwiney and Robertson 2005; Jarecki et al. 2009; Hoben et al. 2011). The Intergovernmental Panel on Climate Change (IPCC) Tier 1 methodologies for national GHG inventories (De Klein et al. 2006) assume an emission factor (EF) for $\mathrm{N}_{2} \mathrm{O}$ emissions from cropped soils to be $1 \%$ of the $\mathrm{N}$ inputs from fertilizer, crop residues, and SOM mineralization where SOM is changing, with an additional premium from drained organic soils (Histosols). Recent evidence suggests that these rates may be even higher at $\mathrm{N}$ input levels that exceed the crop demand for N (McSwiney and Robertson 2005; Ma et al. 2009; van Groenigen et al. 2010; Hoben et al. 2011).

So-called indirect emissions of $\mathrm{N}_{2} \mathrm{O}$ are emitted from downwind and downstream ecosystems when $\mathrm{Nr}$ escapes to areas where conditions for $\mathrm{N}_{2} \mathrm{O}$ production are favorable. Indirect emissions are even more difficult to estimate than direct emissions because there is uncertainty in both the amount of $\mathrm{Nr}$ that escapes and the portion of $\mathrm{N}$ that is then converted to $\mathrm{N}_{2} \mathrm{O}$. IPCC Tier 1 methodologies assume that $0.75 \%$ of the $\mathrm{N}$ that is leached from cropped systems and $1 \%$ of the $\mathrm{N}$ that is volatilized and subsequently deposited to downwind ecosystems are emitted later as $\mathrm{N}_{2} \mathrm{O}$ (De Klein et al. 2006). Recent results suggest that the 
$\mathrm{EF}$ for leached $\mathrm{N}$ depends on the type of waterway (Beaulieu et al. 2011), and it is also likely that the EF's for volatilized and re-deposited $\mathrm{N}$ will vary depending on the $\mathrm{N}$ status (e.g., limiting or non-limiting) of the receiving ecosystem.

\section{Nitrogen oxides emissions}

Emissions of $\mathrm{NO}_{x}$ have increased substantially due to human activities, including agriculture (Houlton et al., this issue). In the mid-1990s, agricultural sources, broadly defined to include residue burning and land clearing, in addition to direct fluxes from soils, were equivalent to all natural sources and comprised about $25 \%$ of all anthropogenic $\mathrm{NO}_{x}$ emissions (Robertson and Vitousek 2009).

In soil the NO that is produced is rapidly oxidized to $\mathrm{NO}_{2}$ in the atmosphere. Soil NO can be produced by chemodenitrification when $\mathrm{HNO}_{2}$ spontaneously decomposes to $\mathrm{NO}$, but more commonly $\mathrm{NO}$ is produced as a metabolic intermediate during nitrification and denitrification (Robertson and Groffman 2007). Cropland $\mathrm{NO}_{x}$ emissions tend to be highly episodic, and in some cropped systems (e.g., Matson et al. 1998) the magnitude of $\mathrm{NO}_{x}$ emissions can rival those of $\mathrm{N}_{2} \mathrm{O}$. In general, however, Stehfest and Bouwman (2006) estimate that global NO-N emissions from cropland and grassland are less than half of the global $\mathrm{N}_{2} \mathrm{O}-\mathrm{N}$ emissions. Most $\mathrm{NO}$ is formed from the same biological sources as $\mathrm{N}_{2} \mathrm{O}$ (i.e., nitrification and denitrification); therefore, $\mathrm{NO}$ emissions are also affected by the same environmental and agronomic factors, including fertilizer application rate and soil moisture.

Although $\mathrm{NO}_{x}$ is not a GHG it plays a substantial role in tropospheric photochemistry (Pinder et al., this issue) affecting atmospheric concentrations of the GHGs $\mathrm{O}_{3}$ and $\mathrm{CH}_{4}$. Eventually $\mathrm{NO}_{x}$ is deposited on downwind ecosystems in gaseous, particulate, or dissolved forms, where it undergoes the same fate as other $\mathrm{Nr}$ inputs, including potential transformation to $\mathrm{N}_{2} \mathrm{O}$.

\section{Methane fluxes}

Lowland rice cultivation represents the only major source of $\mathrm{CH}_{4}$ from established cropping systems; about $40 \mathrm{Tg}$ year $^{-1}$ are emitted from rice soils worldwide (Sass et al. 1999). About $142 \mathrm{Tg}$ year $^{-1}$ of $\mathrm{CH}_{4}$ associated with agriculture are also produced by ruminant livestock, animal waste treatment, and when agricultural residues and land cleared for agriculture are burned (Robertson 2004). However, these sources are not much affected by the use of $\mathrm{N}$ in agriculture. In contrast, the application of organic $\mathrm{N}$ amendments such as farmyard manure, specialty mixes of organic fertilizer, and incorporated cover crops to rice fields generally increase $\mathrm{CH}_{4}$ emissions (Qin et al. 2010). The influence of synthetic fertilizers on $\mathrm{CH}_{4}$ emissions from rice fields is less consistent and not well understood (Zuo et al. 2005).

Methane consumption in soil $\left(\mathrm{CH}_{4}\right.$ oxidation or methanotrophy), in contrast to $\mathrm{CH}_{4}$ production (methanogenesis), is broadly affected by agricultural $\mathrm{N}$ use. Methanotrophic bacteria capable of consuming atmospheric $\mathrm{CH}_{4}$ are found in most aerobic soils, including arable lands, making the uptake of $\mathrm{CH}_{4}$ globally important: The size of the global soil sink of $\mathrm{CH}_{4}$ (about $30 \mathrm{Tg} \mathrm{CH}_{4}$ year $^{-1}$ ) is the same magnitude as the annual atmospheric increase of $\mathrm{CH}_{4}$ (about $37 \mathrm{Tg} \mathrm{CH}_{4}$ year $\left.{ }^{-1}\right)$. In unmanaged ecosystems on well-drained soils, $\mathrm{CH}_{4}$ uptake is co-limited by both the rate at which it diffuses to soil microsites and methanotrph activity (von Fischer et al. 2009). Diffusion is regulated by physical factors-principally moisture but also temperature and soil structure-as well as the concentration of $\mathrm{CH}_{4}$ in the bulk soil atmosphere.

Agricultural management typically diminishes soil $\mathrm{CH}_{4}$ oxidation approximately $70 \%$ or more (Mosier et al. 1991; Robertson et al. 2000; Smith et al. 2000) for at least as long as the soil is farmed. The mechanism for this suppression is not well understood; likely it is related to soil $\mathrm{N}$ availability as affected by enhanced $\mathrm{N}$ mineralization, fertilizer, and other $\mathrm{N}$ inputs (Steudler et al. 1989; Suwanwaree and Robertson 2005). Ammonium is known to competitively inhibit $\mathrm{CH}_{4}$ monooxygenase, the principal enzyme responsible for oxidation at atmospheric concentrations. Recent evidence suggests that microbial diversity may also play an important role (Levine et al. 2011).

While additional agricultural $\mathrm{N}$ use will not much affect $\mathrm{CH}_{4}$ oxidation in already-cropped soils, $\mathrm{Nr}$ that escapes from agricultural to downwind and downstream ecosystems may inhibit $\mathrm{CH}_{4}$ oxidation in those systems, attenuating a significant $\mathrm{CH}_{4}$ sink that would otherwise continue to absorb atmospheric $\mathrm{CH}_{4}$. The degree to which current natural ecosystems are affected is unknown, mainly because most $\mathrm{CH}_{4}$ oxidation experiments to date 
have been conducted with relatively high levels of $\mathrm{N}$ addition.

\section{Tillage and soil C storage}

Nationally, US croplands are in approximate C balance (CAST 2011). An estimated increase of 13 $\mathrm{Tg} \mathrm{C}$ on cropped mineral soils is largely balanced by emissions from cultivated organic soils (Histosols) and from land recently converted to cropland (Ogle et al. 2010; USEPA 2011b). Increases appear to be due to a long-term trend of increasing crop residue production, reductions in tillage intensity (Horowitz et al. 2010), and conversion of annual cropland to perennial grasslands for hay, pasture, and conservation set-asides (CAST 2011).

The influence of $\mathrm{N}$ fertilizer use on cropland soil $\mathrm{C}$ storage is unclear and currently under active debate. On the one hand, the argument is that $\mathrm{N}$ fertilizer increases soil $\mathrm{C}$ because increased above- and belowground residue production parallels increased yields. In addition, because residue $\mathrm{C}: \mathrm{N}$ ratios have not changed, the additional crop residues should contribute to additional soil $\mathrm{C}$ stores (Glendining and Powlson 1995; Powlson et al. 2010). On the other hand, there are studies that document variable effects of inorganic $\mathrm{N}$ on SOM oxidation (Pinder et al., this issue; Neff et al. 2002), with recent studies noting declines in soil $\mathrm{C}$ storage in well-equilibrated, fertilized, long-term plots despite large and steady increases in crop residue inputs (Khan et al. 2007). An additional consideration is the increase in $\mathrm{N}_{2} \mathrm{O}$ fluxes from added fertilizer, which together with the associated $\mathrm{CO}_{2}$ cost of fertilizer manufacture (see next section), can readily and negatively offset the net greenhouse gas benefit of additional soil $\mathrm{C}$ storage.

\section{Greenhouse gas cost of fertilizer manufacture}

The production and transport of fertilizer generates a significant proportion of the GHG emissions associated with crop production (Robertson et al. 2000). Estimates of actual emissions from current industrial fertilizer production vary considerably. Snyder et al. (2009) note estimates that range from 2.2 to $4.5 \mathrm{~kg}$ of $\mathrm{CO}_{2}$-eq $\mathrm{kg}^{-1}$ of $\mathrm{NH}_{3}-\mathrm{N}$. The lower value is for $\mathrm{NH}_{3}$ production using best available technology and the higher value is for the current mix of $\mathrm{N}$ fertilizer sources used in the US, including the average GHG cost of transport. Production of ammonium nitrate $\left(\mathrm{NH}_{4} \mathrm{NO}_{3}\right)$ entails greater $\mathrm{GHG}$ emissions than for anhydrous $\mathrm{NH}_{3}$ or urea.

Only small increases in the efficiency of $\mathrm{NH}_{3}$ production are expected in the short-term. In the longterm, however, if a $\mathrm{C}$-free method can be found to generate hydrogen for the Haber-Bosch process, $\mathrm{NH}_{3}$ could be produced with a much smaller $\mathrm{C}$ footprint.

In Europe, a large fertilizer producer has provided figures for the $\mathrm{C}$ footprint of its $\mathrm{N}$ fertilizer (Yara 2010). They report that manufacture of $\mathrm{NH}_{4} \mathrm{NO}_{3}$ generates $3.6 \mathrm{~kg}$ of $\mathrm{CO}_{2}$-eq kg ${ }^{-1}$ of $\mathrm{N} \mathrm{(2.2} \mathrm{for} \mathrm{the}$ $\mathrm{NH}_{4}{ }^{+}$component plus an additional 1.4 for the $\mathrm{NO}_{3}{ }^{-}$, using best available technology). The transport of the fertilizer adds a further $0.1 \mathrm{~kg}$ of $\mathrm{CO}_{2}$-eq $\mathrm{kg}^{-1}$ of $\mathrm{N}$. In the US, if fertilizer plants were operated with the same best available technology for $\mathrm{NH}_{3}$ manufacture, a lower $\mathrm{C}$ footprint would be expected since $\mathrm{NH}_{4} \mathrm{NO}_{3}$ comprises only a small fraction of total $\mathrm{N}$ fertilizer use. North American producers of $\mathrm{N}$ fertilizers have demonstrated improvements in efficiency and have also committed to reducing the $\mathrm{C}$ footprint of $\mathrm{N}$ fertilizer manufacture to the extent possible.

\section{Opportunities for climate mitigation/adaptation with $\mathbf{N}$ use}

Much of the GHG forcing in agriculture by $\mathrm{N}$ can be reduced, avoided, or offset by $\mathrm{N}$ management practices that minimize GHG emissions and $\mathrm{Nr}$ escape, sequester $\mathrm{C}$, and decrease the likelihood of converting land elsewhere to agricultural production. Many of the effects of these practices interact, so it is important to consider them in concert, from a systems perspective. While many effects are additive, they are combinable to different degrees in different crop and animal systems.

\section{Agricultural intensification}

Agricultural intensification can reduce GHG emissions by reducing the need to newly convert nonfarmed areas to agricultural production. Burney et al. (2010) estimate that gains in crop yields since 1961 have, globally on a net basis, spared emissions of 320-590 Gt $\mathrm{CO}_{2}$-eq. They note that while emissions per unit area of intensified crop (i.e., a cropping 
system's GHG intensity) are higher than those of lower-input crops, the emissions from land conversion associated with extensification are considerably larger. Converting land to crop production entails very large GHG emissions, for instance vegetation removal and the oxidation of SOM upon cultivation releases $\mathrm{CO}_{2}$ and may also affect the $\mathrm{N}$ cycle by increasing $\mathrm{N}_{2} \mathrm{O}$ production for several years following clearing, even in the absence of $\mathrm{N}$ fertilizer.

Burney et al. (2010) further noted that crop yields per unit area increased by more than two-fold from 1961 to 2005, which has limited the expansion in cropland area to $27 \%$. Without these yield increases, they estimated that approximately $300 \%$ more land would have been required to attain the crop production levels of 2005. This foregone GHG release is an important benefit of intensification, especially as intensification could provide opportunities for management interventions not as easily provided in more dispersed systems. Burney et al. (2010) concluded that investment in research toward agricultural intensification (primarily higher crop yields) was a costeffective approach to GHG mitigation, with overall costs of approximately US $\$ 4$ per $\mathrm{Gg}$ of avoided $\mathrm{CO}_{2}$ eq.

Nitrogen management interventions for GHG mitigation in cropping systems

A variety of $\mathrm{N}$ management practices are available to reduce GHG forcing in cropping systems. These range from the way in which $\mathrm{N}$ fertilizer is applied, such as its rate, timing, placement, and formulation, and to changes in human diets. Many appropriate technologies are available now, and require only appropriate incentives to adopt. Other technologies are promising but unproven or not as generalizable.

\section{Fertilizer rate, timing, placement, formulation, and additives}

Applying the right source of $\mathrm{N}$ at the right rate, time, and place is the core concept of $4 \mathrm{R}$ Nutrient Stewardship, supported by a wide range of industry and government organizations (IFA 2009; Bruulsema et al. 2009). The $4 \mathrm{R}$ strategy is designed to increase crop NUE. In general, it is assumed that any practice that increases crop NUE is expected to reduce $\mathrm{N}_{2} \mathrm{O}, \mathrm{NO}_{x}$, and $\mathrm{NH}_{3}$ emissions, because fertilizer $\mathrm{N}$ taken up by the crop is not available to the soil processes that lead to $\mathrm{N}$ emissions, at least in the short term. Thus, strategies to reduce losses of $\mathrm{N}$ are generally associated with improved fertilizer use efficiency.

Practices that improve NUE do not always reduce $\mathrm{N}$ emissions, however. Different fertilizer formulations, for example, can result in different $\mathrm{N}_{2} \mathrm{O}$ emissions regardless of putative NUE effects. Likewise, banded fertilizer placement can increase NUE but in some cases also increase $\mathrm{N}_{2} \mathrm{O}$ emissions, whereas tillage management can increase NUE without affecting $\mathrm{N}_{2} \mathrm{O}$. Thus NUE is generally important but is not sufficient by itself to reduce $\mathrm{N}$ emissions. Fertilizer rate, timing, placement, and formulation can affect NUE and $\mathrm{N}$ gas emissions independently.

Fertilizer rate More than any other factor, the amount of $\mathrm{N}$ fertilizer applied to soil affects the amount of $\mathrm{N}_{2} \mathrm{O}$ and $\mathrm{NO}_{x}$ emitted - in many cases timing, placement, and formulation provide their benefit by effectively reducing fertilizer $\mathrm{N}$ in soil. In this sense, fertilizer rate is a good integrator of multiple practices (Millar et al. 2010).

Fertilizer timing Synchronizing soil $\mathrm{N}$ availability with crop $\mathrm{N}$ demand is a major challenge for efficient fertilizer management. Typically fertilizer is applied well ahead of peak demand, sometimes as much as 6-8 months ahead of crop demand in the case of fallfertilized corn in the Midwest. Although side-dressing fertilizer shortens this lag to weeks, there is still a period when $\mathrm{Nr}$ is more available to microbes than to roots. Moreover, $\mathrm{N}$ emissions are almost always greatest immediately following fertilization when soil $\mathrm{N}$ levels are high and temperature and moisture are sufficient for microbial activity.

Fertilizer placement How fertilizer is applied to soil can affect its availability for crop uptake and also its susceptibility to soil transformations that produce $\mathrm{N}_{2} \mathrm{O}$ and $\mathrm{NO}_{x}$. Placement includes three broad strategies: (1) broadcast application vs. within-row banding; (2) the soil depth to which liquid fertilizer is injected; and (3) uniform application vs. application at different rates within the same field based on the variability of soil fertility across the field. The effects of banding and injection on $\mathrm{N}$ gas emissions are equivocal. Although banding can increase NUE, it can also create zones of highly concentrated soil $\mathrm{N}$ that can increase 
rather than decrease the production of $\mathrm{N}_{2} \mathrm{O}$ (Engel et al. 2010). Deep injection of liquid $\mathrm{N}$ almost always reduces volatilization of $\mathrm{NH}_{3}$ compared with the surface application of manure, urea, and other urea or $\mathrm{NH}_{3}$-containing fertilizers. However, effects on $\mathrm{N}_{2} \mathrm{O}$ production are inconsistent. Variable rate application uses different $\mathrm{N}$ rates for different areas of a field based on expected variations in crop $\mathrm{N}$ demand. This is a new technique and will be discussed more fully later.

\section{Fertilizer formulation and additives Anhydrous $\mathrm{NH}_{3}$} is the most commonly used synthetic fertilizer in the US (35\% of total use), followed by liquid formulations including urea $\mathrm{NH}_{4} \mathrm{NO}_{3}(29 \%)$ and urea (24\%). Early studies found inconsistent effects of fertilizer formulation on $\mathrm{N}$ gas emissions; consequently IPCC GHG inventory guidelines (De Klein et al. 2006) make no distinctions among different formulations or between inorganic and organic forms, although recent cross-site research suggests higher $\mathrm{N}_{2} \mathrm{O}$ emissions with anhydrous ammonia than with broadcast urea (e.g., Venterea et al. 2010). Chemical additives such as urease and nitrification inhibitors delay the transformation of urea and $\mathrm{NH}_{4}{ }^{+}$, respectively, to improve the synchrony between soil $\mathrm{N}$ availability and crop $\mathrm{N}$ demand. Delayed-release chemical formulations such as polymer coated urea slowly release $\mathrm{N}$ with increasing soil temperature and water to achieve the same effect. To date, effects of additives and chemical formulations on $\mathrm{N}_{2} \mathrm{O}$ emissions have been inconsistent, although recent meta-analyses (e.g., Akiyama et al. 2010) suggest that broader experimentation will provide greater clarity.

Integration The 4R Nutrient Stewardship concept is designed to provide farmers a management paradigm that increases the sustainability of the plant system to which it is applied (Fig. 5). For any given system, performance includes the productivity and profitability of the system (the economic dimension of sustainability), its impacts on soil, water, air and biodiversity (the environmental dimension), and its impacts on quality of life and employment opportunities (the social dimension). Farmers ultimately choose the combination of practices that are judged to have the highest probability of meeting economic and environmental goals based on site-specific soil, weather, crop production, and local regulatory conditions. The $4 \mathrm{R}$ Nutrient Stewardship concept is

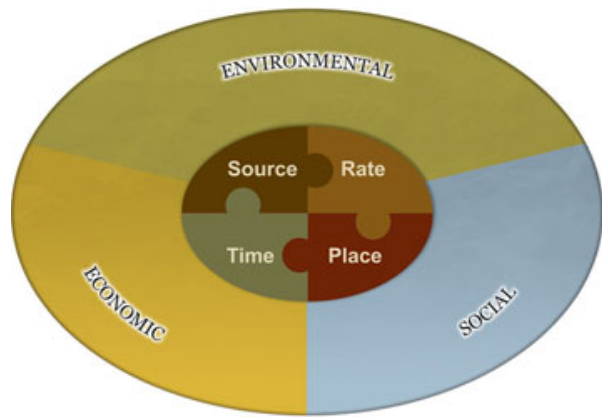

Fig. 5 The 4R nutrient stewardship concept guides farmers to apply $\mathrm{N}$ fertilizer in ways that maximize crop $\mathrm{N}$ use and minimize $\mathrm{N}$ loss to the environment. For any given crop, four decisions largely control fertilizer use efficiency: the source or formulation of the fertilizer (e.g., urea vs. manure); the rate or annual amount of fertilizer applied; the placement of fertilizer in the field (e.g., broadcast vs. subsurface vs. precision applied); and time of fertilizer application (e.g. fall pre-plant vs. at planting vs. during active crop growth). Decisions are informed by environmental, social, and economic concerns (IPNI 2012)

a central component of the Alberta $\mathrm{N}_{2} \mathrm{O}$ Emission Reduction Protocol for $\mathrm{C}$ offset trading (Alberta Environment 2010) and is entrained in many US state Best Management Practice statutes.

\section{Precision fertilizer application technologies}

Although not new concepts to US agriculture, precision technologies and site-specific $\mathrm{N}$ management continue to gain attention as potential methods to improve $\mathrm{N}$ fertilizer use and efficiency. Typically, these methods attempt to integrate fertilizer decisions with field-scale spatial and temporal variations in system characteristics such as soil chemical and physical properties and crop growth patterns. Farmers can now micro-manage their farms using tools such as global positioning systems (GPS) and geographic information systems (GIS) software. When combined with geo-referenced sampling and variable rate application technology, farms are able to more closely match fertilizer applications with crop requirements and thereby improve NUE and reduce environmental losses of Nr.

An example of the potential impact of precision farming technologies on $\mathrm{N}$ management is the growing interest in crop canopy sensor use. Recently, numerous investigations have explored the use of remotely-sensed crop spectral data as a means to understand plant growth characteristics and improve 
$\mathrm{N}$ management for several crops (e.g., Raun et al. 2002). The remotely-sensed normalized difference vegetative index (NDVI) is a measure of total above-ground green biomass and is an indicator of crop growth and health. Use of canopy reflectance and NDVI as an in-season assessment of crop yields can be a valuable tool to finetune $\mathrm{N}$ management, optimizing crop $\mathrm{N}$ fertilizer recovery. Historically, published reports of NDVI data have been remotely-sensed using passive sensing methods such as aerial and satellite imagery. More recently, numerous studies have specifically reported the use of active-light, crop canopy reflectance sensors as a promising tool to improve $\mathrm{N}$ use efficiency by estimating $\mathrm{N}$ requirements and yield potentials for crops including corn, wheat, and sugar beets (Raun et al. 2002, 2005; Girma et al. 2006; Freeman et al. 2007; Dellinger et al. 2008; Barker and Sawyer 2010; Kitchen et al. 2010; Gehl and Boring 2011).

Beyond in-season $\mathrm{N}$ management, NDVI has also been used as a predictor of $\mathrm{N}$ management zones for subsequent crops. Franzen (2004) describes the widespread use of satellite NDVI images for sugar beet canopy $\mathrm{N}$ credits to develop $\mathrm{N}$ management zones for adjusting $\mathrm{N}$ rates for the next crop in the rotation. Continued improvements and advances in available site-specific technologies will increase future opportunities for $\mathrm{Nr}$ mitigation at the farm field-scale by more closely matching inputs with crop needs.

\section{Tillage practices}

The effect of changes in tillage management on soil $\mathrm{N}$ emissions is variable and not fully understood. Shortterm studies have documented increases, decreases, and no changes in soil $\mathrm{N}_{2} \mathrm{O}$ emissions with the adoption of no-till, with responses being principally related to soil texture and structure, climate, fertilizer placement, and time since adoption. In a recent metaanalysis, Six et al. (2004) found that $\mathrm{N}_{2} \mathrm{O}$ emissions are in general higher in the first 10 years after adoption of no-tillage, but over time emissions tended to be lower in humid climates and the same in dry climates. However there are many sites where this generalization does not fit and clarity awaits further research.

\section{Ozone resistant crop cultivars and methane mitigation}

Increasing evidence points to elevated $\mathrm{O}_{3}$ concentrations as being an important and usually overlooked stress in the deceleration of global crop yield increases (Avnery et al. 2011a; Fishman et al. 2010; Van Dingenen et al. 2009; Zhu et al. 2011; Wang and Mauzerall 2004). Recent model simulations quantified the present and potential future (year 2030) impact of surface $\mathrm{O}_{3}$ on the global yields of soybean, maize, and wheat given both upper- and lower-boundary projections of reactive $\mathrm{O}_{3}$ precursor emissions (Avnery et al. 2011a, b). Avnery et al. (2011b) projected substantial future yield losses globally for these crops even under a scenario of stringent $\mathrm{O}_{3}$ control via traditional pollution mitigation measures (i.e., reductions in $\mathrm{NO}_{x}$, VOCs, and NMVOCs): 10-15\% for soybean, 3-9 \% for maize, and $4-17 \%$ for wheat.

Given the potential for significant future $\mathrm{O}_{3}$-induced yield losses, two additional strategies to reduce $\mathrm{O}_{3}$ impacts should be considered: (1) $\mathrm{O}_{3}$ mitigation through $\mathrm{CH}_{4}$ mitigation, and (2) adoption of ozone-resistant cultivars. Methane is both a GHG and an $\mathrm{O}_{3}$ precursor and reductions in $\mathrm{CH}_{4}$ thus provide benefits to human health and vegetation including crops. Avnery et al. (2011a) found that gradual reductions in $\mathrm{CH}_{4}$ emissions between 2005 and 2030 could increase global production of soybean, maize and wheat by $23-102 \mathrm{Tg}$ in 2030 , which is the equivalent of a 2-8\% increase over year 2000 production, worth US $\$ 3.5-15$ billion worldwide $\left(\mathrm{USD}_{2000}\right)$. A wide variation in $\mathrm{O}_{3}$ sensitivity exists both between crops and among crop cultivars. As noted earlier, analyses using minimum and median concentration-response relationships to $\mathrm{O}_{3}$ exposure obtained from the US NCLAN (Heck 1989) showed that the use of existing cultivars with minimum sensitivity to $\mathrm{O}_{3}$ could increase global yields of corn, wheat and soybean $12 \%$ over year 2000 production by 2030 (Avnery et al. 2011a). Combining $\mathrm{CH}_{4}$ mitigation with $\mathrm{O}_{3}$-resistant cultivars would yield the greatest gains to agriculture, although benefits are less than fully cumulative given the nature of the effect of $\mathrm{O}_{3}$ on crops. In any case, there appears to be significant potential to improve global agricultural production without further environmental degradation by reducing $\mathrm{O}_{3}$-induced crop yield losses via reductions in $\mathrm{O}_{3}$ precursors (i.e., $\mathrm{NO}_{x}, \mathrm{CO}$, VOCs, and $\mathrm{CH}_{4}$ ) and by the development and utilization of $\mathrm{O}_{3}$ resistant crop cultivars.

\section{Perennialization of fields and landscapes}

The winter and early spring fallow period common to row crop agriculture creates a significant opportunity 
for $\mathrm{Nr}$ loss (Blevins et al. 1996; Wagner-Riddle and Thurtell 1998; Strock et al. 2004; Dusenbury et al. 2008). Nitrogen that remains in the soil after the summer annual crop is removed is susceptible to loss by leaching (as $\mathrm{NO}_{3}{ }^{-}$) or denitrification $\left(\mathrm{N}_{2} \mathrm{O}, \mathrm{NO}_{x}\right.$, $\mathrm{N}_{2}$ ), particularly if no crop or vegetation is present for $\mathrm{N}$ uptake during the off-season and precipitation is sufficient (Dorsch et al. 2004). Winter cover crops can be used to "perennialize" an annual cropping system by providing nearly year-round plant production, as can the use of perennial rather than annual crops for biofuel feedstocks (Robertson et al. 2011).

The presence of living plants during the winter season can reduce $\mathrm{Nr}$ losses through mechanisms of plant $\mathrm{N}$ uptake and reduced subsurface percolation. Cover crops have been documented to reduce both $\mathrm{N}_{2} \mathrm{O}$ flux and $\mathrm{NO}_{3}{ }^{-}$leaching compared with bare fallow systems (McSwiney et al. 2010). This effect is especially pronounced where manures have been applied after the primary crop growing season (Parkin et al. 2006). However, recent research has indicated that $\mathrm{N}$ fertilizer rate may be more influential to $\mathrm{N}_{2} \mathrm{O}$ emissions when compared with the presence of a cover crop, regardless of cropping system and manure application (Dusenbury et al. 2008; Jarecki et al. 2009)

The establishment of perennial vegetation on cropland can also reduce $\mathrm{Nr}$ losses. Whether established for conservation purposes such as the US Conservation Reserve Program (CRP) or established for cellulosic biofuel production, perennial grasses and short-rotation trees conserve both $\mathrm{N}$ and soil $\mathrm{C}$. The rooting system of some $\mathrm{C}_{4}$ perennial grasses can contribute up to $2.7 \mathrm{Mg} \mathrm{C}^{-1}$ year $^{-1}$ to the top $5 \mathrm{~cm}$ of soil (Lemus and Lal 2005; Schmer et al. 2011). For example, estimated total $\mathrm{C}$ mitigation for giant miscanthus was estimated at $5.2-7.2 \mathrm{Mg} \mathrm{C} \mathrm{ha}{ }^{-1}$ year $^{-1}$ over the course of a 15 year study in Ireland (Clifton-Brown et al. 2007).

Proposed perennial biomass crops generally require relatively low fertilizer $\mathrm{N}$ additions for maximum crop growth and consequently can exhibit low $\mathrm{N}_{2} \mathrm{O}$ emissions (Jørgensen et al. 1997) and other N cycle benefits such as lower $\mathrm{NO}_{3}{ }^{-}$leaching (Robertson et al. 2011). Davis et al. (2011) estimate, using the DAYCENT model, that conversion of US cropland currently used for corn grain ethanol production to perennial cellulosic feedstocks would increase both ethanol and feed production while reducing $\mathrm{NO}_{3}{ }^{-}$leaching $15-122 \%$ and GHG emissions 29-473\%. Empirical research is needed to further improve our understanding of the effects of landscape-level land conversion to perennial biofuel feedstocks on $\mathrm{Nr}$ system dynamics.

Perennialization can also occur as the result of strategic conservation plantings in the landscape. Grass or other vegetative buffer strips in specific topographic locations can intercept $\mathrm{NO}_{3}{ }^{-}$flowing to groundwater and streams, as can natural or restored wetlands, avoiding its conversion to $\mathrm{N}_{2} \mathrm{O}$ and $\mathrm{NO}_{x}$ further downstream (Robertson et al. 2007). Although some $\mathrm{N}_{2} \mathrm{O}$ is likely to be produced at the point of interception, the presumption is that this will be less than would occur were the $\mathrm{Nr}$ allowed to proceed unabated.

\section{Models and other decision support tools}

The complexities of the processes that govern soil $\mathrm{Nr}$ transformations complicate $\mathrm{N}$ fertilizer management decisions for the farmer. These processes are both dynamic and site-specific, requiring growers to make decisions based on past experience while anticipating likelihoods for the current growing season. In essence, growers must plan and manage $\mathrm{N}$ fertility programs that are most likely to give the greatest economic yield. As such, a system of support tools becomes critical to assist growers with $\mathrm{N}$ fertilizer decisions.

Crop response to applied $\mathrm{N}$ varies spatially, both among and within fields, and temporally, from one year to the next. The shape of the crop response curve determines the appropriate fertilization rate. For many crops, the most economic $\mathrm{N}$ rate prevents loss of large surpluses and comes close to minimizing emissions of $\mathrm{N}_{2} \mathrm{O}$ per unit of crop produced (van Groenigen et al. 2010).

The crop response curve to $\mathrm{N}$ additions is unknown at the time of fertilizer application because of uncertain future rates of $\mathrm{N}$ mineralization from SOM. Therefore, the decision on the appropriate $\mathrm{N}$ rate must be made using tools or systems that forecast the most likely crop $\mathrm{N}$ response given soil, crop and weather conditions. Recommendation systems in the US are typically state-specific and vary in approach. Historically, recommendations were primarily based on predicted yield models, but more recently many states have moved toward economic response models that may or may not include predicted yield. An example is the maximum return to $\mathrm{N}$ (MRTN) recommendation tool recently adopted by seven Midwest states. The 
MRTN approach uses recent response trial data from individual state or local regions to determine the $\mathrm{N}$ fertilizer rate where economic net return to $\mathrm{N}$ application is greatest (Sawyer et al. 2006). The MRTN is a regional model based on historic response curves for specific geographies. As a decision support tool, the factors used in generating the recommendation include fertilizer and crop prices.

An approach that goes further toward including additional factors relevant to $\mathrm{N}$ rate prediction are process-based models such as Maize-N (Setiyono et al. 2011) and System Approach to Land Use Sustainability (SALUS) (Basso et al. 2011). While this approach is more deterministic and less empirical than MRTN, it is still based on historical climate data and could be adapted to anticipate dynamic weather conditions that influence the prediction of potentially attainable yields and yields without $\mathrm{N}$ fertilizer.

Weather controls a great deal of the variation in a crop's response to $\mathrm{N}$. The application of models integrating soil water flow, soil $\mathrm{N}$ dynamics, and plant uptake can potentially improve the prediction of crop $\mathrm{N}$ needs in response to weather conditions. An example of a model that includes dynamic weather factors is Adapt-N (Moebius-Clune et al. 2011).

Nutrient management becomes more complex when animal manure is used in the cropping system. Since the relative concentrations of manure nutrients (e.g., the N:P ratio) are fixed, it is more difficult to match available nutrients to crop needs. Nutrient management plans are generally designed to assure that manure nutrients are applied at the appropriate time and rates for crop use, thus reducing losses to the environment. Software tools such as the Manure Management Planner (Joern 2010) assist producers in the development of nutrient management plans that make best use of available manure nutrients along with inorganic fertilizers.

Animal system $\mathrm{N}$ management practices that mitigate GHG forcing

Mitigation of $\mathrm{N}$ loss from animal agriculture must begin with improved utilization of feed protein and then continue with the reduction of emissions from manure. More precise feeding of the amount and type of protein (amino acids) needed to meet the animal's requirements at each stage of production is necessary to reduce the excretion of manure $\mathrm{N}$ while maintaining or improving animal production. Even with a precise feeding strategy large amounts of $\mathrm{N}$ are excreted, so further mitigation must be obtained through strategies that reduce $\mathrm{N}$ losses from manure. The final opportunity is to capture $\mathrm{N}$ compounds before they escape to the environment.

\section{Animal nutrition}

For precision feeding, the protein and other nutrient requirements of the animals must be known, and then a diet must be prepared that meets that requirement without feeding in excess. Implementing precision feeding strategies is challenging, particularly for ruminant animals as noted earlier. The first challenge is discerning the nutrient content of available feeds. While the ability to measure the chemical and physical characteristics of feeds on-farm is improving, feed sampling and analytical procedures are still relatively imprecise, particularly for forages (Moore et al. 2007). With imprecision in measuring the major feed ingredients, there is error in knowing the amounts of supplemental protein needed to balance rations. The second challenge is proper mixing and delivery of the feeds so that the animals consistently receive the nutrients needed (Rippel et al. 1998). Inconsistencies in the diet can reduce NUE, reducing animal productivity and increasing nutrient losses to the environment.

Reducing the total protein in the diet can have a major impact on the environmental effects of N. For example, multiple studies with dairy and beef animals have shown that $\mathrm{N}$ excretion and its potential loss to the environment decreases $10-20 \%$ for every percentage unit of protein removed from the diet (Hristov et al. 2011; Rotz 2004; Erickson and Klopfenstein 2010). To effectively remove that protein, the remaining feed protein must better meet the requirements of the animal at a particular stage of development. This can only be achieved through precise blending of available feeds. Phase feeding can help by dividing and feeding animals according to their stage in development (Erickson and Klopfenstein 2010). However, as the diet becomes more finely tuned to the animal's requirements, the animal becomes more sensitive to inconsistencies in the feed. Thus, producers tend to reduce their risk by over feeding protein and other nutrients to assure that the requirements of the animals are met. The use of precision feeding is increasing, however, and there can be an economic 
incentive for the producer through a reduction in feed costs.

Synthetic amino acids can be also fed for further precision in meeting animal protein requirements. Different amounts of each amino acid are required, and these amounts vary with animal age and other characteristics. As we learn more about amino acid requirements and we learn to produce these compounds cost effectively for feed use, more precise diets can be created to match the animals' requirements throughout their life cycle. The use of synthetic amino acids has become common in non-ruminant animal production, but their use in ruminant diets is more complex (Han and Lee 2000; Hristov et al. 2011).

\section{Manure handling}

Mitigation of $\mathrm{N}$ effects through changes in manure handling begins in the housing facility. For cattle and swine, floor designs have been developed to separate urine from feces (Ndegwa et al. 2008). When urine has less contact with the urease enzyme in the feces, the transformation of urea to $\mathrm{NH}_{4}{ }^{+}$, and ultimately $\mathrm{NH}_{3}$, is reduced. This strategy has reduced the emission of $\mathrm{NH}_{3}$ from dairy barns by up to $50 \%$. Other strategies such as using a flushing system to remove manure or more frequent scraping may also provide some reduction in $\mathrm{NH}_{3}$ emission, but this benefit has not been clearly supported through on-farm studies (Ndegwa et al. 2008). On open lots, the use of organic bedding material, increasing manure removal frequency, and acidifying manure have all shown potential for reducing $\mathrm{NH}_{3}$ emissions (Erickson and Klopfenstein 2010). For poultry, the use of catching boards to dry the manure have reduced $\mathrm{NH}_{3}$ emission by $40-60 \%$ (Yang et al. 2000), and the use of belt removal systems have reduced emissions by up to $90 \%$ (Groot Koerkamp 1994).

With long-term manure storage, $\mathrm{NH}_{3}$ emissions can be reduced using a cover. Many cover designs have been evaluated including floating straw, expanded clay pebbles, geotextile fabric, and other permeable materials. Emissions are reduced up to $80 \%$ by impeding emissions and promoting biological activity that transforms gaseous compounds (Petersen and Miller 2006). However, complete cover must be maintained throughout the storage period, and this is often difficult to achieve. The development of a natural crust of manure solids appears to be about as effective as the use of other permeable covering materials. However, with a natural crust or other permeable cover, an environment is created that enhances $\mathrm{N}_{2} \mathrm{O}$ production via nitrification and denitrification (Petersen and Miller 2006). An enclosed tank or impermeable plastic cover provides the most effective mitigation strategy for manure storage, virtually eliminating $\mathrm{N}$ emissions (Ndegwa et al. 2008; Rotz 2004). A floating layer of oil has also been evaluated as an impermeable cover (Ndegwa et al. 2008).

Mitigating $\mathrm{N}$ emissions from manure also requires careful management of field applications. Direct injection into soil is the most effective method for reducing $\mathrm{NH}_{3}$ emission when it is compatible with the cropping system. With deep injection, $\mathrm{NH}_{3}$ loss can be as little as $2 \%$ of the $\mathrm{N}$ applied (Ndegwa et al. 2008; Rotz 2004). With more shallow injection, this loss may be up to a third of that associated with broadcast application (Rotz et al. 2011). However, within the concentrated layer of manure placed in soil, $\mathrm{N}_{2} \mathrm{O}$ emission can increase soon after application, providing up to a fourfold increase in average annual emissions (Velthof and Mosquera 2011). The amount of $\mathrm{N}_{2} \mathrm{O}$ emitted is variable and highly dependent on soil characteristics, soil moisture content, and the amount and time of year manure is applied.

Band application is another option, whereby manure is spread on the soil surface in bands, reducing the exposed manure surface compared to broadcast application. Depending upon the width and structure of the bands and the crop receiving the manure, emissions of $\mathrm{NH}_{3}$ are reduced up to $50 \%$ compared to broadcast application (Pfluke et al. 2011). Other techniques that can reduce $\mathrm{NH}_{3}$ emissions following surface application are to reduce the dry matter content of the manure, which increases soil infiltration, and to apply the manure with fewer but heavier applications (Sommer and Hutchings 2001; Rotz 2004). Adding acid to drop the $\mathrm{pH}$ of the manure is also effective but cost prohibitive (Sommer and Hutchings 2001). Applying manure before rain or irrigation can reduce $\mathrm{NH}_{3}$ emission, but this may increase nutrient runoff losses in surface water (Vadas et al. 2011).

\section{Grazing land management}

Management can be used to reduce $\mathrm{N}$ loss from grazing animals, but the benefit of these changes may 
be small and implementation may be impractical. As with confinement fed animals, the first step is to use supplemental protein feeds efficiently, and thus reduce urinary $\mathrm{N}$ excretion. These measures are more challenging with grazing animals since there is uncertainty in knowing the amount and type of protein they are obtaining from pasture forage (Fales et al. 1995).

Nitrogen loss from grazing lands can be controlled by avoiding overstocking and importing forage and other supplemental feeds. Furthermore, movement of watering and supplemental feeding areas improves nutrient distribution, thus increasing plant uptake and reducing loss. Volatile loss of $\mathrm{Nr}$ may be reduced by irrigating the paddock immediately after grazing to wash the $\mathrm{N}$ into the sod and soil. Leaching loss of $\mathrm{NO}_{3}{ }^{-}$is best reduced by avoiding grazing in the late autumn or winter when plant uptake of $\mathrm{N}$ is low. Removing the autumn growth through silage harvest can help reduce the accumulation of excess soil $\mathrm{NO}_{3}{ }^{-}$, which at that time of the year will likely be lost by leaching (Stout et al. 1997). Less use of $\mathrm{N}$ fertilizer with greater use of clover and other legumes to supply needed forage $\mathrm{N}$ can also reduce soil $\mathrm{N}$ levels and leaching loss. Di and Cameron (2002) decreased leaching $\mathrm{N}$ loss by $60 \%$ and decreased denitrification losses by $82 \%$ by applying a nitrification inhibitor, but practical application of this technology is difficult and likely not cost effective for the producer.

\section{Animal housing}

Adaptation to climate change will require changes in animal housing facilities, including better insulation and greater use of evaporative cooling systems. Coping with increasing temperature in outdoor facilities and pastures may require greater use of shading systems to protect animals from solar radiation and water spray systems for increasing the evaporative cooling of animals. Genetic manipulation of animals to develop greater tolerance to heat may also help in this adaptation (Nardone et al. 2010). If animals cannot be fully adapted to future climate changes, decreases in the efficiency of production will increase losses of $\mathrm{N}$ per unit of production.

After $\mathrm{N}$ compounds are created and released from the manure there can be an opportunity to capture the compounds before they disperse into the environment. For example, biofilters and scrubbers can be used to remove $\mathrm{NH}_{3}$ from the ventilation air exiting enclosed housing facilities (Ndegwa et al. 2008). Scrubbers capture the $\mathrm{NH}_{3}$ in an acid water solution while biofilters biologically degrade or convert trapped compounds into environmentally benign forms.

\section{Whole-farm approaches}

Management to reduce $\mathrm{N}$ losses in animal production requires a whole-farm approach. Many changes can be made to reduce $\mathrm{N}$ losses in each step of manure management between animal excretion and crop uptake. However, the benefit for reducing the loss in any one component is low if steps are not taken to reduce losses occurring in other components (Rotz et al. 2005; Rotz and Oenema 2006). For example, reducing $\mathrm{NH}_{3}$ emission in the housing facility has little benefit if that retained $\mathrm{N}$ is simply lost due to poor management during subsequent manure storage and field application. Reducing $\mathrm{NH}_{3}$ emissions may also not provide any overall benefit if the conserved manure $\mathrm{N}$ not lost as $\mathrm{NH}_{3}$ leads to over application on crop fields and thus greater losses through denitrification and leaching (Rotz et al. 2011). The loss of $\mathrm{N}_{2} \mathrm{O}$ to the atmosphere and $\mathrm{NO}_{3}{ }^{-}$to groundwater may have a greater long-term cost to society than $\mathrm{NH}_{3}$ emission. Only by providing similar levels of management to animal feeding, housing, manure storage, and field application can production systems be developed with reduced or optimal environmental impact.

The primary deterrent to the mitigation of $\mathrm{N}$ losses and their impacts on the environment in animal agriculture is normally the economic effect on the producer. Often the changes in technology and management required increase the producer's cost of production. Whole farm analyses indicate that minor changes in feeding management, covered manure storages, and the direct injection of manure into the soil can be performed with less cost to the producer than more major changes such as altered barn or housing design, enclosed manure storages, and manure treatments (Rotz et al. 2006). However, since the profit margin is often tight and the product price is beyond the control of the producer, this additional cost usually cannot be absorbed. If further mitigation of $\mathrm{N}$ emissions from agriculture is desired by society, then society will likely need to bear the cost either through regulations that increase agricultural product prices or government subsidies. 
Human diet

The life-cycle efficiency of $\mathrm{N}$ varies greatly between plant and animal food systems. While approximately $70 \%$ of $\mathrm{N}$ in harvested food crops becomes available for human consumption after processing losses, only about $15 \%$ of the original $\mathrm{N}$ in harvested feed crops is present in meat, eggs, and dairy products (Smil 2002). This is the direct result of $\mathrm{N}$ leakage to the environment from intensive animal systems and of the demand for increased crop production for animal feed $-70 \%$ of the annual cereal and legume harvest in the US is fed to livestock (Smil 2001). Consequently, continued high meat consumption in developed countries and more meat-intensive diets in developing countries over the coming century will lead to the need for greater $\mathrm{N}$ inputs and thus greater $\mathrm{N}$ losses from agriculture (Mosier et al. 2001).

For the US, less food waste and changes in diet could significantly reduce $\mathrm{N}$ fertilizer consumption without comprising nutritional adequacy. Smil (2001) calculates that a reduction in meat consumption by $33 \%$ would reduce fertilizer consumption by $25 \%$, with total fertilizer use dropping from 7-7.5 to 5.3-5.6 Tg N.

Current policy initiatives

\section{US policy}

Policy in the US regarding $\mathrm{N}$ mitigation inadvertently began in the 1930s as part of the New Deal. The New Deal National Industrial Recovery Act (1933) authorized the USDA to work on soil erosion control as a means of unemployment relief through the Civilian Conservation Corps (Rasmussen 1982; Cox 2007). Soon following, the Soil Conservation Act (1935) established a permanent federal agency, the Soil Conservation Service (SCS). The SCS provided direct assistance to farmers with the help of state legislation. Subsequent acts such as the 1936 Soil Conservation and Domestic Allotment Act began to provide payments to farmers to produce soil-conserving legumes and grasses. The Act also provided payments to farmers to incorporate productivity-enhancing practices on land that was already in production. Financial support for conservation was a means to increase profitability, manage supply, and raise prices.

The shift in agricultural policy from resource conservation to environmental benefits began with the 1977 Food and Agriculture Act. The Act specified that eligibility under the Agricultural Conservation Program (ACP) be based on the presence of an environmental problem that either reduced the productive capacity of a farm's land and water resources or caused environmental degradation. Specifically, the ACP required that the Secretary of Agriculture consider the need to control erosion and sedimentation, water resources, and pollution from animal wastes in order to encourage voluntary compliance in solving environmental issues, and to consider the degree to which ACP assistance would contribute to a continuous supply of food and fiber and improved water quality in rural America (Rasmussen 1982; Cox 2007).

The Food Security Act of 1985 accelerated the shift from agricultural resource conservation with on-farm benefits to environmental management with off-farm benefits. Off-farm benefits included clean water and air, biodiversity, and other ecological services. The Act also authorized the CRP, which was designed to control the supply of surplus crops and to take highly erodible land out of production. The CRP would later go beyond erodible land to include conservation priority areas such as the Chesapeake Bay, Long Island Sound, and Great Lakes watersheds, as well as state water quality priority areas, and critical areas suitable for high-priority conservation practices such as buffers (Barbarika 2001; Cox 2007). The Chesapeake Bay Watershed Initiative, for example, assists with conservation practices that improve water quality and quantity and restores, enhances and preserves soil, air, and related resources. Provisions of subsequent farm bills (1990, 1996, 2002, and 2008) reflected a change in the conservation agenda. Provisions of the farm bill such as the Environmental Quality Incentives Program (EQIP) also include natural resource concerns related to poultry and livestock production. Eligible practices under EQIP include nutrient management, integrated pest management, irrigation water management, and wildlife habitat management.

The U.S. Department of Agriculture (USDA) has been the leading federal department, with the Natural Resource Conservation Service (NRCS) and the Farm Service Agency (FSA) the leading federal agencies for agricultural conservation and environmental management on private land. Of the 20 programs currently managed, CRP and EQIP represent $64 \%$ of the $\$ 5$ billion FY2011 appropriations (Stubbs 2011). The 20-year history of CRP has provided a wealth of 
knowledge regarding the impact of conservation practices at the field level, and is therefore the most studied conservation program. However, few research studies have been designed to measure the larger effects of conservation practices. Current efforts to quantify the impacts of conservation practices in the US have been under the banner of the national Conservation Effects Assessment Project (CEAP), which was established to quantify environmental benefits of conservation programs on agricultural landscapes at the national, regional and watershed scales. It is an ongoing mix of data collection, model development, model application, and research. Since its inception in 2003, CEAP has grown into a multiagency, multi-resource effort.

US policy has developed since the New Deal, going beyond the initial focus on reducing soil erosion and increasing farm production. Although these policies were specific to soil erosion, conservation policies have also been important in mitigating $\mathrm{Nr}$ losses from agricultural lands. Current efforts now include environmental management and improvements leading to clean water and air.

\section{International policies}

There are several existing regional and international policy efforts that attempt to limit $\mathrm{N}$ leakages to the surrounding environment. However, only a few deal directly with $\mathrm{N}$ emissions related to climate change. One is the United Nations Framework Convention on Climate Change Kyoto Protocol. Nitrous oxide is in the Kyoto basket of controlled GHGs. However, there are no specific controls on $\mathrm{N}_{2} \mathrm{O}$, and to date no agricultural $\mathrm{N}_{2} \mathrm{O}$ emission reduction protocols have been approved for Clean Development Mechanism projects.

The Alberta Quantification Protocol for Agricultural $\mathrm{N}_{2} \mathrm{O}$ Emissions Reductions issues voluntary $\mathrm{C}$ offset credits for on-farm reductions of $\mathrm{N}_{2} \mathrm{O}$ emissions and fuel use associated with the management of fertilizer, manure, and crop residues. Presumed reductions are achieved via Beneficial Nitrogen Management Practices (BNMPs) that implement the 4R Nitrogen Stewardship Plan. Millar et al. (2010) have proposed a rate-based $\mathrm{N}_{2} \mathrm{O}$ emission reduction protocols for the Verified Carbon Standard, the American Carbon Registry, and the Climate Action Reserve.

There are also two European policy initiatives that deal indirectly with $\mathrm{N}$ leakages related to climate change. The EU Nitrates Directive sets limits on the use of fertilizer $\mathrm{N}$ and animal manure $\mathrm{N}$ (limited to $170 \mathrm{~kg} \mathrm{~N} \mathrm{ha}^{-1}$ year ${ }^{-1}$ ) in $\mathrm{NO}_{3}{ }^{-}$vulnerable zones, which are declared by member states where surface or groundwater concentrations of $\mathrm{NO}_{3}{ }^{-}$exceed $50 \mathrm{mg} / \mathrm{l}$, or where $\mathrm{NO}_{3}{ }^{-}$concentrations are increasing over time. These limits potentially reduce $\mathrm{NO}_{3}{ }^{-}$leaching and subsequent $\mathrm{N}_{2} \mathrm{O}$ emissions via denitrification in downstream waterways. The Convention on the Long Range Transport of Air Pollution and its Gothenburg Protocol set national limits for $\mathrm{NO}$ and $\mathrm{NH}_{3}$ emissions for its parties with an aim to limit eutrophication, acidification and tropospheric $\mathrm{O}_{3}$ pollution, which in turn impacts the effects of $\mathrm{Nr}$ on climate change.

While some of these policies are more successful than others, an over-arching critique applies to all of them: by examining only specific parts of the $\mathrm{N}$ cycle, these efforts could control one form of $\mathrm{N}$ pollution while exacerbating another. For example, one of the consequences of the EU Nitrates Directive is more prevalent winter manure storage. However, recent evidence suggests that this leads to more $\mathrm{NH}_{3}$ volatilization, detrimental to air quality. The central lesson that should be drawn from these policies is that any effort to limit $\mathrm{N}$ pollution should be done in as holistic a manner as possible so as to minimize potential negative side effects. A useful concept to apply here is the economic $\mathrm{N}$ cascade, which is an evaluation of the costs and benefits of reducing $\mathrm{Nr}$ pollution at various points of the cascade as recently applied in the Chesapeake Bay watershed (Birch et al. 2011).

\section{Research needs}

We identify four major research needs for a better understanding of the impact of climate- $\mathrm{N}$ interactions in agriculture. First is an improved understanding of agricultural $\mathrm{N}$ cycle responses to changing climate. This includes the response of $\mathrm{N}$ emissions both direct and indirect to changes in the frequency and intensity of rainfall; the response of $\mathrm{N}$ emissions to changes in regional temperature patterns, and in particular to warmer winters and longer and hotter growing seasons; and the response of crop $\mathrm{N}$ cycles to $\mathrm{O}_{3}$-tolerant crop varieties.

The second research need is for an integrated, systems-level understanding of important crop and 
animal systems sufficient to identify key interactions and feedbacks. This understanding will allow us to design interventions that maximize synergies and minimize liabilities, and above all avoid unanticipated outcomes with unpleasant surprises.

Third is a need to further develop and test models capable of predicting $\mathrm{N}$-climate interactions with confidence across a wide variety of crop-soil-climate combinations. Models will include biogeochemical estimators for important $\mathrm{N}$ species such as $\mathrm{N}_{2} \mathrm{O}$ and $\mathrm{NO}_{x}$. Currently needed are model intercomparisons and a sufficient number of data sets to validate and further refine existing models. Models should also include decision support tools for growers and animal managers to improve $\mathrm{N}$ management decisions based on available practices and best possible outcomes.

Finally, socioecological research is needed to better understand the incentives necessary to achieve meaningful deployment of realistic solutions. In many cases knowledge and technology are available to abate and even mitigate effects of agricultural $\mathrm{N} \times$ climate interactions. Currently missing are the policy or market incentives that will lead farmers towards adoption.

Acknowledgments This work resulted from a workshop supported by NSF Research Coordination Network awards DEB-0443439 and DEB-1049744 and by the David and Lucille Packard Foundation. We also acknowledge support for individual authors from the US Department of Energy (BER DE-FC0207ER64494) and NSF Long-term Ecological Research Program (GPR).

Open Access This article is distributed under the terms of the Creative Commons Attribution License which permits any use, distribution, and reproduction in any medium, provided the original author(s) and the source are credited.

\section{References}

Akiyama H, Yan XY, Yagi K (2010) Evaluation of effectiveness of enhanced-efficiency fertilizers as mitigation options for $\mathrm{N}_{2} \mathrm{O}$ and NO emissions from agricultural soils: metaanalysis. Glob Change Biol 16:1837-1846

Alberta Environment (2010) Quantification protocol for agricultural nitrous oxide emissions reductions. Government of Alberta, Canada. http://environment.gov.ab.ca/info/library/ 8294.pdf. Accessed 10 Feb 2012

Avnery S, Mauzerall DL, Liu J, Horowitz LW (2011a) Global crop yield reductions due to surface ozone exposure: 2 . Year 2030 potential crop production losses and economic damage under two scenarios of $\mathrm{O}_{3}$ pollution. Atmos Environ 45:2297-2309
Avnery S, Mauzerall DL, Liu J, Horowitz LW (2011b) Global crop yield reductions due to surface ozone exposure: 1 . Year 2000 crop production losses and economic damage. Atmos Environ 45:2284-2296

Barbarika A (2001) The Conservation Reserve Program: Program summary and enrollment statistics as of August 2001. U.S. Department of Agriculture, Farm Service Agency, Washington. http://www.fsa.usda.gov/Internet/FSA_File /fy2001.pdf. Accessed 28 Aug 2011

Barker DW, Sawyer JE (2010) Using active canopy sensors to quantify nitrogen stress and nitrogen application rate. Agron J 102:964-971

Basso B, Ritchie JT, Cammarano D, Sartori L (2011) A strategic and tactical management approach to select optimal $\mathrm{N}$ fertilizer rates for wheat in a spatially variable field. Eur J Agron 35:215-222

Beaulieu JJ, Tank JL, Hamilton SK, Wollheim WM, Hall RO Jr, Mulholland PJ, Peterson BJ, Ashkenas LR, Cooper LW, Dahm CN, Dodds WK, Grimm NB, Johnson SL, Mcdowell WH, Poole GC, Valett HM, Arango CP, Bernot MJ, Burgin AJ, Crenshaw CL, Helton AM, Johnson LT, O'Brien JM, Potter JD, Sheibley RW, Sobota DJ, Thomas SM (2011) Nitrous oxide emission from denitrification in stream and river networks. Proc Natl Acad Sci USA 108:214-219

Bergsma TT, Robertson GP, Ostrom NE (2002) Influence of soil moisture and land use history on denitrification end-products. J Environ Qual 31:711-717

Birch MBL, Gramig BM, Moomaw WR, Doering OC, Reeling CJ (2011) Why metrics matter: evaluating policy choices for reactive nitrogen in the Chesapeake Bay Watershed. Environ Sci Technol 45:168-174

Blevins DW, Wilkison DH, Kelly BP, Silva SR (1996) Movement of nitrate fertilizer to glacial till and runoff from a claypan soil. J Environ Qual 25:584-593

Borken W, Savage K, Davidson EA, Trumbore SE (2006) Effects of experimental drought on soil respiration and radiocarbon efflux from a temperate forest soil. Glob Change Biol 12:177-193

Bouwman AF, Fung I, Matthews E, John J (1993) Global analysis of the potential for $\mathrm{N}_{2} \mathrm{O}$ production in natural soils. Global Biogeochem Cycles 7:557-597

Bruulsema TW, Lemunyon J, Herz W (2009) Know your fertilizer rights. Crops Soils 42(2):13-18

Burney JA, Davis SJ, Lobell DB (2010) Greenhouse gas mitigation by agricultural intensification. Proc Natl Acad Sci USA 107:12052-12057

Butterbach-Bahl K, Kahl M, Mykhayliv L, Werner C, Kiese R, Li C (2009) A European-wide inventory of soil NO emissions using the biogeochemical models DNDC/ForestDNDC. Atmos Environ 43:1392-1402

Canadell JG, Le Quere C, Raupach MR, Field CB, Buitenhuis ET, Ciais P, Conway TJ, Gillett RA, Houghton RA, Marland G (2007) Contributions to accelerating atmospheric $\mathrm{CO}_{2}$ growth from economic activity, carbon intensity, and efficiency of natural sinks. Proc Natl Acad Sci USA 104:18866-18870

Cantarel A, Bloor J, Deltroy N, Soussana J-F (2011) Effects of climate change drivers on nitrous oxide fluxes in an upland temperate grassland. Ecosystems 14:223-233

CAST (Council for Agricultural Science and Technology) (2004) Climate change and greenhouse gas mitigation: 
Challenges and opportunities for agriculture. Task Force Report No. 141. CAST, Ames

CAST (Council for Agricultural Science and Technology) (2011) Carbon sequestration and greenhouse gas fluxes in agriculture: challenges and opportunities. Task Force Report No.142. CAST, Ames

Clifton-Brown JC, Breuer J, Jones MB (2007) Carbon mitigation by the energy crop, Miscanthus. Glob Change Biol 13: 2296-2307

Conant RT, Drijber RA, Haddix ML, Parton WJ, Paul EA, Plante AF, Six J, Steinweg JM (2008) Sensitivity of organic matter decomposition to warming varies with its quality. Glob Change Biol 14:868-877

Cox C (2007) U.S. Agriculture conservation policy and programs: History, trends, and implications. In: Kraush A, Josling T, Sumner DA, Thompson BH (eds) U.S. Agricultural Policy and the 2007 Farm Bill. Woods Institute of the Environment, Stanford, pp 113-146. http://woods.stan ford.edu/docs/farmbill/farmbill_book.pdf. Accessed 28 Aug 2011

Davidson EA (1992) Sources of nitric oxide and nitrous oxide following wetting of dry soil. Soil Sci Soc Am Proc 56: 95-102

Davidson EA, Ackerman IL (1993) Changes in soil carbon inventories following cultivation of previously untilled soils. Biogeochemistry 20:161-193

Davidson EA, Janssens IA (2006) Temperature sensitivity of soil carbon decomposition and feedbacks to climate change. Nature 440:165-173

Davidson EA, Nepstad DC, Ishida FY, Brando PM (2008) Effects of an experimental drought and recovery on soil emissions of carbon dioxide, methane, nitrous oxide, and nitric oxide in a moist tropical forest. Glob Change Biol 14:2582-2590

Davidson EA, David MB, Galloway JN, Goodale CL, Haeuber R, Harrison J, Howarth RW, Jaynes DB, Lowrance RR, Nolan BT, Peel JL, Pinder RW, Porter E, Snyder CS, Towsend AR, Ward MH, Whitney P (2012) Excess nitrogen in the U.S. environment: trends, risks and solutions. Issues Ecol, Report No. 15

Davis SC, Parton WJ, Del Grosso SJ, Keough C, Marx E, Adler PR, DeLucia EH (2011) Impact of second-generation biofuel agriculture on greenhouse-gas emissions in the corngrowing regions of the US. Front Ecol Environ 10:69-74

De Klein C, Nova RSA, Ogle S, Smith KA, Rochette P, Wirth TC, McConkey BG, Mosier A, Rypdal K (2006) $\mathrm{N}_{2} \mathrm{O}$ emissions from managed soils, and $\mathrm{CO}_{2}$ emissions from lime and urea application. In: Eggleston HS, Buendia L, Miwa K, Ngara T, Tanabe K (eds) 2006 IPCC guidelines for national greenhouse gas inventories, vol 4. Agriculture, forestry and other land use. Institute for Global Environmental Strategies (IGES), Intergovernmental Panel on Climate Change (IPPC), Kanagawa, Japan, pp 11.11-11.54

Dellinger AE, Schmidt JP, Beegle DB (2008) Developing nitrogen fertilizer recommendations for corn using an active sensor. Agron J 100:1546-1552

Di HJ, Cameron KC (2002) The use of a nitrification inhibitor, dicyandiamide (DCD), to decrease nitrate leaching and nitrous oxide emissions in a simulated grazed and irrigated grassland. Soil Use Manag 18:395-403
Dorsch P, Palojarvi A, Mommertz S (2004) Overwinter greenhouse gas fluxes in two contrasting agricultural habitats. Nutr Cycl Agroecosyst 70:117-133

Dusenbury MP, Engel RE, Miller PR, Lemke RL, Wallander R (2008) Nitrous oxide emissions from a northern great plains soil as influenced by nitrogen management and cropping systems. J Environ Qual 37:542-550

Emberson LD, Büker P, Ashmore MR, Mills G, Jackson LS, Agrawal M, Atikuzzaman MD, Cinderby S, Engardt M, Jamir C, Kobayashi K, Oanh NTK, Quadir QF, Wahid A (2009) A comparison of North American and Asian exposure-response data for ozone effects on crop yields. Atmos Environ 43:1945-1953

Emmett BA, Beier C, Estiarte M, Tietema A, Kristensen HL, Williams D, Peñuelas J, Schmidt I, Sowerby A (2004) The response of soil processes to climate change: results from manipulation studies of shrublands across an environmental gradient. Ecosystems 7:625-637

Engel R, Liang DL, Wallander R, Bembenek A (2010) Influence of urea fertilizer placement on nitrous oxide production from a silt loam soil. J Environ Qual 39:115-125

Erickson G, Klopfenstein T (2010) Nutritional and management methods to decrease nitrogen losses from beef feedlots. J Anim Sci 88:E172-E180

ERS (Economic Research Service) (2011) Livestock, dairy, and poultry outlook: Tables. U.S. Department of Agriculture, Washington. http://www.ers.usda.gov/Publications/LDP/ LDPTables.htm. Accessed on 10 Feb 2012

ERS (Economic Research Service) (2012) Data sets. Fertilizer use and price. U.S. Department of Agriculture, Washington. http://www.ers.usda.gov/Data/FertilizerUse/. Accessed 10 Feb 2012

Fales SL, Muller LD, Ford SA, O'Sullivan M, Hoover RJ, Holden LA, Lanyon LE, Buckmaster DR (1995) Stocking rate affects production and profitability in a rotationally grazed pasture system. J Prod Agric 8:88-96

Fischer G, Shah M, Tubiello FN, van Velhuizen H (2005) Socioeconomic and climate change impacts on agriculture: an integrated assessment, 1990-2080. Philos Trans R Soc B 360:2067-2083

Fishman J, Creilson JK, Parker PA, Ainsworth EA, Vining GG, Szarka J, Booker FL, Xu XJ (2010) An investigation of widespread ozone damage to the soybean crop in the upper Midwest determined from ground-based and satellite measurements. Atmos Environ 44:2248-2256

Forster P, Ramsaswamy P, Artaxo T, Bernsten T, Betts R, Fahey DW, Haywood J, Lean J, Lowe DC, Myhre G, Nganga J, Prinn R, Raga G, Schultz M, Van Dorland R (2007) Changes in atmospheric constituents and in radiative forcing. In: Solomon D, Qin D, Manning M et al (eds) Climate change 2007: The physical science basis. Contribution of Working Group I to the Fourth Assessment of the Intergovernmental Panel on Climate Change. Cambridge University Press, Cambridge, pp 129-234

Franzen DW (2004) Delineating nitrogen management zones in a sugarbeet rotation using remote sensing-a review. J Sugar Beet Res 41:47-60

Freeman KW, Girma K, Arnall DB, Mullen RW, Martin KL, Teal RK, Raun WR (2007) By-plant prediction of corn forage biomass and nitrogen uptake at various growth 
stages using remote sensing and plant height. Agron J 99: 530-536

Galloway JN, Aber JD, Erisman JW, Seitzinger SP, Howarth RW, Cowling EB, Cosby BJ (2003) The nitrogen cascade. Bioscience 53:341-356

Gehl RJ, Boring TJ (2011) In-season prediction of sugarbeet yield, quality, and nitrogen status using an active sensor. Agron J 103:1012-1018

Gehl RJ, Schmidt JP, Stone LR, Schlegel AJ, Clark GA (2005) In situ measurements of nitrate leaching implicate poor nitrogen and irrigation management on sandy soils. J Environ Qual 34:2243-2254

Gelfand I, Zenone T, Jasrotia P, Chen J, Hamilton SK, Robertson GP (2011) Carbon debt of Conservation Reserve Program (CRP) grasslands converted to bioenergy production. Proc Nat Acad Sci USA 108:13864-13869

Gènermont S, Cellier P (1997) A mechanistic model for estimating ammonia volatilization from slurry applied to bare soil. Agric For Meteorol 88:145-167

Girma K, Martin KL, Anderson RH, Arnall DB, Brixey KD, Casillas MA, Chung B, Dobey BC, Kamenidou SK, Kariuki SK, Katsalirou EE, Morris JC, Moss JQ, Rohla CT, Sudbury BJ, Tubana BS, Raun WR (2006) Mid-season prediction of wheat-grain yield potential using plant, soil, and sensor measurements. J Plant Nutr 29:873-897

Glendining MJ, Powlson DS (1995) The effects of long continued applications of inorganic nitrogen fertilizer on soil organic nitrogen: a review. In: Lal R, Stewart BA (eds) Soil management: experimental basis for sustainability and environmental quality. Lewis Publishers, Boca Raton, pp 385-446

Grandy AS, Robertson GP (2006) Initial cultivation of a temperate-region soil immediately accelerates aggregate turnover and $\mathrm{CO}_{2}$ and $\mathrm{N}_{2} \mathrm{O}$ fluxes. Glob Change Biol 12:1507-1520

Groot Koerkamp PWG (1994) Review on emissions of ammonia from housing systems for laying hens in relation to sources, processes, building design and manure handling. J Agric Eng Res 59:73-87

Han I, Lee J (2000) The role of synthetic amino acids in monogastric animal production. Asian Austral J Anim 13: 543-560

Harper LA, Sharpe RR, Parkin TB, De Visscher A, van Cleemput O, Byers FM (2004) Nitrogen cycling through swine production systems: ammonia, dinitrogen, and nitrous oxide emissions. J Environ Qual 33:1189-1201

Hatfield J, Boote K, Fay D, Hahn L, Izaurralde C, Kimball BA, Mader T, Morgan J, Ort D, Polley W, Thomson A, Wolfe D (2008) The effects of climate change on agriculture, land resources, water resources, and biodiversity in the United States. In: Backlund P, Janetos A, Schimel D et al (eds) Synthesis and assessment Product 4.3. U. S. Department of Agriculture, Washington, pp 21-74

Hatfield JL, Boote KJ, Kimball BA, Ziska LH, Izaurralde RC, Ort D, Thomson AM, Wolfe D (2011) Climate impacts on agriculture: implications for crop production. Agron J 103: 351-370

Heagle AS (1989) Ozone and crop yield. Annu Rev Phytopathol 27:397-423

Heck WW (1989) Assessment of crop losses from air pollutants in the United States. In: MacKenzie JJ, El-Ashry MT (eds)
Air pollution's toll on forests and crops. Yale University Press, New Haven, pp 235-315

Heffer P, Prud'homme M (2011) Fertilizer outlook 2011-2015. International Fertilizer Industry Association (IFA), Paris

Hoben JP, Gehl RJ, Millar N, Grace PR, Robertson GP (2011) Nonlinear nitrous oxide $\left(\mathrm{N}_{2} \mathrm{O}\right)$ response to nitrogen fertilizer in on-farm corn crops of the US Midwest. Glob Change Biol 17:1140-1152

Horowitz J, Ebel R, Ueda K (2010) "No-till" farming is a growing practice. U.S. Department of Agriculture, Economic Research Service, Economic Information Bulletin No. EIB070. http://www.ers.usda.gov/Publications/EIB 70/EIB70_ReportSummary.pdf. Accessed 10 Feb 2012

Houghton JT, Ding Y, Griggs DJ, Noguer M, van der Linden PJ, Dai X, Maskell K, Johnson CA (eds) (2001) Climate change 2001: the scientific basis. Contribution of Working Group I to the Third Assessment Report of the Intergovernmental Panel on Climate Change (IPCC). Cambridge University Press, New York

Houlton BZ, Boyer E, Finzi A, Galloway J, Leach A, Liptzin D, Melillo J, Rosenstock TS, Sobota D, Townsend AR (2012) Intentional versus unintentional nitrogen use in the United States: trends, efficiency and implications. Biogeochemistry. doi:10.1007/s10533-012-9801-5

Hristov ANHAN, Hanigan M, Cole A, Todd R, McAllister TA, Ndegwa PM, Rotz A (2011) Review: ammonia emissions from dairy farms and beef feedlots. Can J Anim Sci 91: $1-35$

Hudman RC, Russell AR, Valin LC, Cohen RC (2010) Interannual variability in soil nitric oxide emissions over the United States as viewed from space. Atmos Chem Phys 10:9943-9952

IFA (International Fertilizer Industry Association) (2009) The global "4R" nutrient stewardship framework: developing fertilizer best management practices for delivering economic, social and environmental benefits. Drafted by the IFA Task Force on Fertilizer Best Management Practices, Paris

IPCC (Intergovernmental Panel on Climate Change) (2001) Climate change 2001: The scientific basis. Contribution of Working Group I to the Third Assessment Report of the Intergovernmental Panel on Climate Change. Cambridge University Press, New York

IPNI (International Plant Nutrition Institute) (2012) In: Bruulsema TW, Fixen PE, Sulewski GD (eds) 4R plant nutrition manual: a manual for improving the management of plant nutrition. International Plant Nutrition Institute, Norcross, GA, USA

Jacob DJ, Winner DA (2009) Effect of climate change on air quality. Atmos Environ 43:51-63

Jaeglé L, Steinberger L, Martin RV, Chance K (2005) Global partitioning of $\mathrm{NO}_{\mathrm{x}}$ sources using satellite observations: relative roles of fossil fuel combustion, biomass burning and soil emissions. Faraday Disc 130:407-423

Jarecki MK, Parkin TB, Chan ASK, Kaspar TC, Moorman TB, Singer JW, Kerr BJ, Hatfield JL, Jones R (2009) Cover crop effects on nitrous oxide emission from a manure-treated Mollisol. Agric Ecosyst Environ 134:29-35

Joern B (2010) Manure management planner. Agronomy Department, Purdue University. http://www.agry.purdue. edu/mmp/. Accessed 16 Sep 2011 
Jørgensen RN, Jørgensen BJ, Nielsen NE, Maag M, Lind AM (1997) $\mathrm{N}_{2} \mathrm{O}$ emission from energy crop fields of Miscanthus "Giganteus" and winter rye. Atmos Environ 31:2899-2904

Karl M, Guenther A, Koble R, Leip A, Seufert G (2009) A new European plant-specific emission inventory of biogenic volatile organic compounds for use in atmospheric transport models. Biogeosciences 6:1059-1087

Keshavarz K, Austic RE (2004) The use of low-protein, lowphosphorus, aminoacid- and phytase-supplemented diets on laying hen performance and nitrogen and phosphorus excretion. Poult Sci 83:75-83

Khan SA, Mulvaney RL, Ellsworth TR, Boast CW (2007) The myth of nitrogen fertilization for soil carbon sequestration. J Environ Qual 36:1821-1832

Kitchen NR, Sudduth KA, Drummond ST, Scharf PC, Palm HL, Roberts DF, Vories ED (2010) Ground-based canopy reflectance sensing for variable-rate nitrogen corn fertilization. Agron J 102:71-84

Knorr W, Prentice IC, House JI, Holland EA (2005) Long-term sensitivity of soil carbon turnover to warming. Nature 433: 298-301

Krupa SV, Nosal M, Legge AH (1998) A numerical analysis of the combined open-top chamber data from the USA and Europe on ambient ozone and negative crop responses. Environ Pollut 101:157-160

Lanyon LE, Beegle DB (1989) The role of on-farm nutrient balance assessments in an integrated approach to nutrient management. J Soil Water Conserv 44:164-168

Larsen KS, Andresen LC, Beier C, Jonasson S, Albert KR, Ambus P, Arndal MF, Carter MS, Christensen S, Holmstrup M, Ibrom A, Kongstad J, van der Linden L, Maraldo K, Michelsen A, Mikkelsen TN, Pilegaard K, Prieme A, Ro-Poulsen H, Schmidt IK, Selsted MB, Stevnbak K (2011) Reduced N cycling in response to elevated $\mathrm{CO}_{2}$, warming, and drought in a Danish heathland: synthesizing results of the CLIMAITE project after two years of treatments. Glob Change Biol 17:1884-1899

Leakey ADB, Ainsworth EA, Bernacchi CJ, Rogers A, Long SP, Ort DR (2009) Elevated $\mathrm{CO}_{2}$ effects on plant carbon, nitrogen, and water relations: six important lessons from FACE. J Exp Bot 60:2859-2876

Lemus R, Lal R (2005) Bioenergy crops and carbon sequestration. Crit Rev Plant Sci 24:1-21

Levine U, Teal K, Robertson GP, Schmidt TM (2011) Agriculture's impact on microbial diversity and associated fluxes of carbon dioxide and methane. ISME J 5:1683-1691

Linquist B, van Groenigen KJ, Adviento-Borbe MA, Pittelkow C, van Kessel C (2012) An agronomic assessment of greenhouse gas emissions from major cereal crops. Glob Change Biol 18:194-209

Lobell DB, Schlenker W, Costa-Roberts J (2011) Climate trends and global crop production since 1980. Science 333: 616-620

Long SP, Ainsworth EA, Leakey ADB, Morgan PB (2005) Global food insecurity: treatment of major food crops with elevated carbon dioxide or ozone under large-scale fully open-air conditions suggests recent models may have overestimated future yields. Philos Trans R Soc B 360:2011-2020

Luo Y, Mooney HA (eds) (1999) Carbon dioxide and environmental stress. Academic Press, San Diego
Ma BL, Wu TY, Tremblay N, Deen W, Morrison MJ, McLaughlin NB, Gregorich EG, Stewart G (2009) Nitrous oxide fluxes from corn fields: on-farm assessment of the amount and timing of nitrogen fertilizer. Glob Change Biol 16:156-170

Matson PA, Naylor R, Ortiz-Monasterio I (1998) Integration of environmental, agronomic, and economic aspects of fertilizer management. Science 280:112-115

Mauzerall DL, Wang XP (2001) Protecting agricultural crops from the effects of tropospheric ozone exposure: reconciling science and standard setting in the United States, Europe, and Asia. Annu Rev Energy Environ 26:237-268

McSwiney CP, Robertson GP (2005) Non-linear response of $\mathrm{N}_{2} \mathrm{O}$ flux to incremental fertilizer addition in a continuous maize (Zea mays sp.) cropping system. Glob Change Biol 11:1712-1719

McSwiney CP, Snapp SS, Gentry LE (2010) Use of N immobilization to tighten the $\mathrm{N}$ cycle in conventional agroecosystems. Ecol Appl 20:648-662

Meehl GA, Stocker TF, Collins WD, Friedlingstein P, Gaye AT, Gregory JM, Kitoh A, Knutti R, Murphy JM, Noda A, Raper SCB, Watterson IG, Weaver AJ, Zhao Z-C (2007) Global climate projections. In: Solomon S, Qin D, Manning M et al (eds) Climate change 2007: The physical science basis. Contribution of Working Group I to the Fourth Assessment Report of the Intergovernmental Panel on Climate Change. Cambridge University Press, Cambridge

Meyer D, Ristow PL, Lie M (2007) Particle size and nutrient distribution in fresh dairy manure. Appl Eng Agric 23: 113-117

Millar N, Robertson GP, Grace PR, Gehl RJ, Hoben JP (2010) Nitrogen fertilizer management for nitrous oxide $\left(\mathrm{N}_{2} \mathrm{O}\right)$ mitigation in intensive corn (Maize) production: an emissions reduction protocol for US Midwest agriculture. Mitig Adapt Strateg Glob Change 15:185-204

Moebius-Clune B, van Es HM, Melkonian JJ (2011) Adapt-N: an adaptive nitrogen management tool for corn production. Cornell University, Ithaca. http://adapt-n.cals.cornell.edu/ pubs/pdfs/Factsheet1_IntroToAdaptN.pdf. Accessed 10 Feb 2012

Montes F, Rotz CA, Chaoui H (2009) Process modeling of ammonia volatilization from ammonium solution and manure surfaces: a review with recommended models. Trans ASABE 52:1707-1719

Moore JE, Adesogan AT, Coleman SW, Undersander DJ (2007) Predicting forage quality. In: Barnes RF, Nelson CJ, Moore KJ, Collins M (eds) Forages: the science of grassland agriculture. Blackwell, Ames, pp 553-568

Mosier AR, Schimel D, Valentine D, Bronson K, Parton W (1991) Methane and nitrous oxide fluxes in native, fertilized and cultivated grasslands. Nature 350:330-332

Mosier AR, Bleken MA, Pornipol C, Ellis EC, Freney JR, Howarth RB, Matson PA, Minami K, Naylor R, Weeks KN, Zhu Z (2001) Policy implications of human-accelerated nitrogen cycling. Biogeochemistry 52:281-320

Nardone A, Ronchi B, Lacetera N, Ranieri MS, Bernabucci U (2010) Effects of climate changes on animal production and sustainability of livestock systems. Livest Sci 130:57-69

Ndegwa PM, Hristov AN, Arogo J, Sheffield RE (2008) A review of ammonia emission mitigation techniques for 
concentrated animal feeding operations. Biosyst Eng 100:453-469

Neff JC, Townsend AR, Gleixner G, Lehman SJ, Turnbull J, Bowman WD (2002) Variable effects of nitrogen additions on the stability and turnover of soil carbon. Nature 419: 915-917

NRC (National Research Council) (1991) Rethinking the ozone problem in urban and regional air pollution. National Academy Press, Washington, DC

NRC (National Research Council) (1994) Nutrient requirements of poultry: ninth revised edition. National Academy Press, Washington

NRC (National Research Council) (1998) Nutrient requirements of swine: tenth revised edition. National Academy Press, Washington

NRC (National Research Council) (2000) Nutrient requirements of beef cattle: seventh revised edition: Update 2000. National Academy Press, Washington

NRC (National Research Council) (2001) Nutrient requirements of dairy cattle: seventh revised edition, 2001. National Academy Press, Washington

Ogle SM, Breidt FJ, Easter M, Williams S, Killian K, Paustian K (2010) Scale and uncertainty in modeled soil organic carbon stock changes for US croplands using a process-based model. Glob Change Biol 16:810-822

Parkin TB, Kaspar TC, Singer JW (2006) Cover crop effects on the fate of $\mathrm{N}$ following soil application of swine manure. Plant Soil 289:141-152

Peer JL, Haeuber R, Garcia V, Russell AG, Neas L (2012) Impact of nitrogen and climate change interactions on ambient air pollution and human health. Biogeochemistry. doi:10.1007/s 10533-012-9782-4

Petersen SO, Miller DN (2006) Greenhouse gas mitigation by covers on livestock slurry tanks and lagoons? J Sci Food Agric 86:1407-1411

Pfluke PD, Jokela WE, Bosworth SC (2011) Ammonia volatilization from surface-banded and broadcast application of liquid dairy manure on grass forage. J Environ Qual 40:374-382

Powlson DS, Jenkinson AE, Johnston PR, Poulton MJ, Glendining MJ, Goulding KWT (2010) Comments on "Synthetic nitrogen fertilizers deplete soil nitrogen: a global dilemma for sustainable cereal production" by R.L. Mulvaney, S.A. Khan, and T.R. Ellsworth in the Journal of Environmental Quality 2009 38:2295-2314. J Environ Qual 39:749-752

Prinn RG (2004) Non- $\mathrm{CO}_{2}$ greenhouse gases. In: Field CB, Raupach MR (eds) The global carbon cycle. Island Press, Washington, pp 205-216

Qin Y, Liu S, Guo Y, Liu Q, Zou J (2010) Methane and nitrous oxide emissions from organic and conventional rice cropping systems in Southeast China. Biol Fertility Soils 46:825-834

Rasmussen WD (1982) History of soil conservation, institutions and incentives. In: Halcrow HG, Heady EO, Cotner ML (eds) Soil conservation policies, institutions, and incentives. Soil Conservation Society of America, Ankeny, pp 3-18

Raun WR, Solie JB, Johnson GV, Stone ML, Mullen RW, Freeman KW, Thomason WE, Lukina EV (2002) Improving nitrogen use efficiency in cereal grain production with optical sensing and variable rate application. Agron J 94:815-820
Raun WR, Solie JB, Stone ML, Martin KL, Freeman KW, Mullen RW, Zhang H, Schepers JS, Johnson GV (2005) Optical sensor-based algorithm for crop nitrogen fertilization. Commun Soil Sci Plant Anal 36:2759-2781

Ribaudo M, Delgado JA, Hansen L, Livingston M, Mosheim R, Williamson J (2011) Nitrogen in agricultural systems: implications for conservation policy. ERR-127. U.S. Department of Agriculture, Economic Research Service, Washington

Rippel CM, Jordan ER, Stokes SR (1998) Evaluation of particle size distribution and ration uniformity in total mixed rations fed in Northcentral Texas. Prof Anim Sci 14:44-50

Robertson GP (1997) Nitrogen use efficiency in row crop agriculture: crop nitrogen use and soil nitrogen loss. In: Jackson L (ed) Ecology in agriculture. Academic Press, New York, pp 347-365

Robertson GP (2004) Abatement of nitrous oxide, methane, and the other non- $\mathrm{CO}_{2}$ greenhouse gases: the need for a systems approach. In: Field CB, Raupach MR (eds) The global carbon cycle. Island Press, Washington, pp 493-506

Robertson GP, Groffman PM (2007) Nitrogen transformations. In: Paul EA (ed) Soil microbiology, ecology, and biochemistry. Academic Press, Burlington, pp 341-364

Robertson GP, Vitousek PM (2009) Nitrogen in agriculture: balancing the cost of an essential resource. Annu Rev Environ Resour 34:97-125

Robertson GP, Paul EA, Harwood RR (2000) Greenhouse gases in intensive agriculture: contributions of individual gases to the radiative forcing of the atmosphere. Science 289 : 1922-1925

Robertson GP, Burger LW, Kling CL, Lowrance R, Mulla DJ (2007) New approaches to environmental management research at landscape and watershed scales. In: Schnepf M, Cox C (eds) Managing agricultural landscapes for environmental quality. Soil and Water Conservation Society, Ankeny, pp 27-50

Robertson GP, Hamilton SK, Del Grosso SJ, Parton WJ (2011) The biogeochemistry of bioenergy landscapes: carbon, nitrogen, and water considerations. Ecol Appl 21:10551067

Rooke JA, Hatfield D (2003) Biochemistry of ensiling. In: Buxton DR, Muck RE, Harrison JH (eds) Silage science and technology. American Society of Agronomy, Madison, pp 95-139

Rotz CA (2004) Management to reduce nitrogen losses in animal production. J Anim Sci (Suppl) 82:E119-E137

Rotz CA, Muck RE (1994) Changes in forage quality during harvest and storage. In: Fahey GC Jr (ed) Forage quality, evaluation, and utilization. American Society of Agronomy, Madison, pp 828-868

Rotz CA, Oenema J (2006) Predicting management effects on ammonia emissions from dairy and beef farms. Trans ASABE 49:1139-1149

Rotz CA, Taube F, Russelle MP, Oenema J, Sanderson MA, Wachendorf M (2005) Whole-farm perspectives of nutrient flows in grassland agriculture. Crop Sci 45:2139-2159

Rotz CA, Oenema J, van Keulen H (2006) Whole farm management to reduce nutrient losses from dairy farms: a simulation study. Appl Eng Agric 22:773-784

Rotz CA, Kleinman PJA, Dell CJ, Veith TL, Beegle DB (2011) Environmental and economic comparisons of manure 
application methods in farming systems. J Environl Qual 40:438-448

Sardans J, Peñuelas J, Estiarte M (2008) Changes in soil enzymes related to $\mathrm{C}$ and $\mathrm{N}$ cycle and in soil $\mathrm{C}$ and $\mathrm{N}$ content under prolonged warming and drought in a Mediterranean shrubland. Appl Soil Ecol 39:223-235

Sass RL, Fisher FM, Ding A (1999) Exchange of methane from rice fields: national, regional, and global budgets. J Geophys Res 104:26943-26951

Sawyer JE, Nafziger ED, Randall GW, Bundy LG, Rehm GW, Joern BC (2006) Concepts and rationale for regional nitrogen rate guidelines for corn. Publ. PM2015. Iowa State University Extension, Ames

Schlenker W, Roberts MJ (2009) Nonlinear temperature effects indicate severe damages to U.S. crop yields under climate change. Proc Natl Acad Sci USA 106:15594-15598

Schmer MR, Liebig MA, Vogel KP, Mitchell RB (2011) Fieldscale soil property changes under switchgrass managed for bioenergy. GCB Bioenergy 3:439-448

Senthilkumar S, Basso B, Kravchenko AN, Robertson GP (2009) Contemporary evidence for soil carbon loss in the U.S. corn belt. Soil Sci Soc Am J 73:2078-2086

Setiyono TD, Yang H, Walters DT, Dobermann A, Ferguson RB, Roberts DF, Lyon DJ, Clay DE, Cassman KG (2011) Maize-N: a decision tool for nitrogen management in maize. Agron J 103:1276-1283

Six J, Ogle SM, Breidt FJ, Conant RT, Mosier AR, Paustian K (2004) The potential to mitigate global warming with notillage management is only realized when practised in the long term. Glob Change Biol 10:155-160

Smil V (2001) Enriching the earth: Fritz Haber, Carl Bosch, and the transformation of world food production. The MIT Press, Cambridge

Smil V (2002) Nitrogen and food production: proteins for human diets. Ambio 31:126-131

Smith KA, Dobbie KE, Ball BC, Bakken LR, Situala BK, Hansen S, Brumme R (2000) Oxidation of atmospheric methane in Northern European soils, comparison with other ecosystems, and uncertainties in the global terrestrial sink. Glob Change Biol 6:791-803

Snyder CS, Bruulsema TW, Jensen TL, Fixen PE (2009) Review of greenhouse gas emissions from crop production systems and fertilizer management effects. Agric Ecosyst Environ 133:247-266

Soder KJ, Muller LD (2007) Case study: use of partial total mixed rations on pasture-based dairy farms in Pennsylvania and New York. Prof Anim Sci 23:300-307

Sommer SG, Hutchings NJ (2001) Ammonia emission from field applied manure and its reduction-invited paper. Eur J Agron 15:1-15

Sommer SG, Gènermont S, Cellier P, Hutchings NJ, Olesen JE, Morvan T (2003) Processes controlling ammonia emission from livestock slurry in the field. Eur J Agron 19:465-486

Stehfest E, Bouwman L (2006) $\mathrm{N}_{2} \mathrm{O}$ and $\mathrm{NO}$ emission from agricultural fields and soils under natural vegetation: summarizing available measurement data and modeling of global annual emissions. Nutr Cycl Agroecosyst 74: 207-228

Steudler PA, Bowden RD, Melillo JM, Aber JD (1989) Influence of nitrogen fertilization on methane uptake in temperate forest soils. Nature 341:314-316
Stout WL, Fales SA, Muller LD, Schnabel RR, Priddy WE, Elwinger GF (1997) Nitrate leaching from cattle urine and feces in northeast USA. Soil Sci Soc Am J 61:1787-1794

St-Pierre NR, Cobanov B, Schnitkey G (2003) Economic losses from heat stress by US livestock industries. J Dairy Sci (Suppl) 86:E52-E77

Strock JS, Porter PM, Russelle MP (2004) Cover cropping to reduce nitrate loss through subsurface drainage in the northern US Corn Belt. J Environ Qual 33:1010-1016

Stubbs M (2011) Agricultural conservation: a guide to programs. Congressional Research Service. www.nationalag1 awcenter.org/assets/crs/R40763.pdf. Accessed 28 Aug 2011

Suwanwaree P, Robertson GP (2005) Methane oxidation in forest, successional, and no-till agricultural ecosystems: effects of nitrogen and soil disturbance. Soil Sci Soc Am J 69:1722-1729

Tenkorang F, Lowenberg-DeBoer J (2009) Forecasting longterm global fertilizer demand. Nutr Cycl Agroecosyst 83: 233-247

USDA (U.S. Department of Agriculture) (2011) U.S. Agriculture and Forestry Greenhouse Gas Inventory: 1990-2008. Climate Change Program Office, Office of the Chief Economist, Technical Bulletin No. 1930, 159 pp

USEPA (U.S. Environmental Protection Agency) (1996) Air quality criteria for ozone and related photochemical oxidants. U.S. Environmental Protection Agency, Washington, pp. 1-1e1-1-1e1-33

USEPA (U.S. Environmental Protection Agency) (2011a) Reactive nitrogen in the United States: an analysis of inputs, flows, consequence, and management options. Report EPA-SAB-11-013. Washington

USEPA (U.S. Environmental Protection Agency) (2011b) Inventory of U. S. greenhouse gas emissions and sinks: 1990-2009. Report EPA 430-R-11-005. Washington, DC

USGCRP (United States Global Change Research Program) (2009) In: Karl TR, Melillo JM, Peterson TC (eds) Global climate change impacts in the United States. Cambridge University Press, New York

Vadas PA, Jokela WE, Franklin DH, Endale DM (2011) The effect of rain and runoff when assessing timing of manure application and dissolved phosphorus loss in runoff. J Am Water Resour Assess 47:877-886

Van Dingenen R, Dentener FJ, Raes F, Krol MC, Emberson L, Cofala J (2009) The global impact of ozone on agricultural crop yields under current and future air quality legislation. Atmos Environ 43:604-618

van Groenigen J, Velthof G, Oenema O, van Groenigen K, van Kessel $\mathrm{C}$ (2010) Towards an agronomic assessment of $\mathrm{N}_{2} \mathrm{O}$ emissions: a case study for arable crops. Eur J Soil Sci 61:903-913

van Kessel C, Clough T, van Groenigen JW (2009) Dissolved organic nitrogen: an overlooked pathway of nitrogen loss from agricultural systems? J Environ Qual 38:393-401

Van Soest PJ (1994) Nutritional ecology of the ruminant, 2nd edn. Cornell University Press, Ithaca

Velthof GL, Mosquera J (2011) The impact of slurry application technique on nitrous oxide emission from agricultural soils. Agric Ecosyst Environ 140:298-308

Venterea RT, Dolan MS, Ochsner TE (2010) Urea decreases nitrous oxide emissions compared with anhydrous ammonia in a Minnesota corn cropping system. Soil Sci Soc Am J $74: 407-418$ 
von Fischer JC, Butters G, Duchateau PC, Thelwell RJ, Siller R (2009) In situ measures of methanotroph activity in upland soils: a reaction-diffusion model and field observations of water stress. J Geophys Res 114:G0101. doi:10.1029/2008 JG000731

Wagner-Riddle C, Thurtell GW (1998) Nitrous oxide emissions from agricultural fields during winter and spring thaw as affected by management practices. Nutr Cycl Agroecosyst 52:151-163

Wang X, Mauzerall DL (2004) Characterizing distributions of surface ozone and its impact on grain production in China, Japan and South Korea: 1990 and 2020. Atmos Environ 38:4384-4402

Wheeler TR, Craufurd PQ, Ellis RH, Porter JR, Vara Prasad PV (2000) Temperature variability and the yield of annual crops. Agric Ecosyst Environ 82:159-167

Wollenweber B, Porter JR, Schellberg J (2003) Lack of interaction between extreme high-temperature events at vegetative and reproductive growth stages in wheat. J Agron Crop Sci 189:142-150
Yang P, Lorimor JC, Xin H (2000) Nitrogen losses from laying hen manure in commercial high-rise layer facilities. Trans ASAE 43:1771-1780

Yara (2010) The carbon footprint of fertilizers. http://www.yara. com/doc/29413_Yara_carbon_life_cycle.pdf. Accessed 10 Feb 2012

Yienger JJ, Levy H II (1995) Empirical model of global soilbiogenic $\mathrm{NO}_{x}$ emissions. J Geophys Res 100:11447-11464

Zhu X, Feng Z, Sun T, Liu X, Tang H, Zhu J, Guo W, Kobayashi K (2011) Effects of elevated ozone concentration on yield of four Chinese cultivars of winter wheat under fully openair field conditions. Glob Change Biol 17:2697-2706

Zuo J, Huang Y, Jiang J, Zheng X, Sass RL (2005) A 3-year field measurement of methane and nitrous oxide emissions from rice paddies in China: effects of water regime, crop residue, and fertilizer application. Global Biogeochem Cycles 19:GB2021. doi:10.1029/2004GB002401 